\title{
IMAGEN Y PALABRA EN LA EVANGELIZACIÓN Y CATEQUESIS DE LA RUTA DE LA PLATA. POTOSI-ARICA
}

\author{
POR \\ FERNANDO GUZMÁN \\ Profesor asociado de la Universidad Adolfo Ibáñez \\ PAOLA CORTI \\ Profesora asistente de la Universidad Adolfo Ibáñez \\ MAGDALENA PEREIRA \\ Investigadora de la Fundación Altiplano
}

\section{RESUMEN}

El presente trabajo se propone reconstruir, a través del estudio de las pinturas murales en las iglesias ubicadas en la Ruta de la Plata y del análisis de los catecismos del Tercer Concilio limense, la forma como podría haber operado el método de evangelización y catequesis fundado en la trilogía: palabra escuchada, fórmula memorizada, imagen contemplada y recordada. Buscando proponer de qué manera esa articulación modificaba o determinaba la observación o la recordación de las pinturas religiosas o, en la dirección contraria, de qué forma las pinturas observadas o la imagen de ellas en la memoria daban forma a la vida cristiana de quienes habitaban este territorio.

\section{PALABRAS CLAVE}

Pintura mural; catequesis; imagen; memoria; palabra. 


\section{THE RELATIONSHIP BETWEEN IMAGE AND SPOKEN WORD IN THE CHRISTIANIZATION AND THE CATECHESIS PROCESS IN THE SILVER ROUTE. POTOSI-ARICA}

\section{ABSTRACT}

The following article intends to recreate, by means of studying a number of wall paintings in the churches located in the "Ruta de la Plata" (Silver route trade between Potosi mining village and Arica's port), analyzing the catechisms of the Third Council of Lima (1584), the way in which the Christianization and catechesis process took place in these locations. Based in the trilogy listened word, memorized formula, and contemplated-remembered image of the religious paintings, the research purpose is focused on detecting how that particular articulation modified or determined the remembrance that the observers made of them. In addition, it will deepen in the way the paintings were observed, and in the images that were created in memory, figuring how they gave life to a particular Christian experience for the inhabitants of this territory.

\section{KEY WORDS}

Wall paintings; catechesis; image; remembrance; heard and written word

$\begin{array}{ll}\text { Recibido/Received } & 04-02-2013 \\ \text { Aceptado/Accepted } & 02-07-2014\end{array}$

\section{INTRODUCCIÓN}

Afirmar que las imágenes pintadas cumplieron un papel decisivo en la evangelización y catequesis durante el período colonial, articulándose con los sermones y la memorización del catecismo, no reviste novedad alguna: ${ }^{1}$ sin embargo, no son habituales los estudios de caso que

1 Los trabajos que apuntan al uso de las imágenes pictóricas o escultóricas en la evangelización y catequesis de la América colonial son demasiado abundantes para recogerlos en su totalidad, sin embargo se pueden mencionar algunas publicaciones emblemáticas: Gruzinski, S. 1991. La colonización de lo imaginario. Sociedades indígenas y occidentalización en el México español. Siglos XVI-XVII: México: Fondo de Cultura Económica. Siracusano, G. 2009. El poder de los colores. De lo material a lo simbólico en las prácticas culturas andinas. Siglos XVI-XVIII: Buenos Aires: Fondo de 
permitan conocer cómo funcionó esta red de palabas y representaciones visuales en una iglesia concreta. La reflexión en torno a lo que pudo ocurrir en comunidades, como las de la Ruta de la Plata, puede ayudar a precisar o cuestionar ciertas afirmaciones de carácter general. ${ }^{2}$

La tarea de reconstruir -para sitios bien determinados- la forma concreta en que operaban imágenes y palabras en la evangelización y catequesis, puede toparse con el escollo de no contar con documentos que recojan antecedentes relevantes para estructurar un relato. Teniendo esto en cuenta, la indagación se orienta en primer lugar a reconstruir los específicos puntos de contacto entre los sermones, las fórmulas del catecismo y las imágenes pictóricas en estudio. En segundo lugar se describe la forma en que los sacerdotes, habituados a las prácticas clásicas y medievales del arte de la memoria, habrían concebido la retención e interacción de conceptos e imágenes. Finalmente, se presentan las formas andinas de memoria, identificando las posibles interferencias entre la lógica occidental y las prácticas locales.

El artículo propone una forma posible de comprender la memorización e interacción de palabras e imágenes; ofreciendo una explicación conjetural acerca del modo en que los sacerdotes concebían la catequesis, intentando comprender en qué medida los aymara pudieron adaptarse a prácticas culturales desconocidas para ellos. La amplitud de los asuntos involucrados obliga a presentar un texto que no contiene soluciones cerradas, sino que, por el contrario, aporta un conjunto de antecedentes y reflexiones que permiten abrir una discusión académica.

El análisis se ha acotado al contexto geográfico de la Ruta de la Plata, aquel circuito comercial que unía la ciudad de Potosí con el puerto de Arica y por el cual se transportó -durante más de dos siglos- el mineral de plata que se extraía del Cerro Rico. ${ }^{3}$ La zona geográfica y cultural que comprende la Ruta de la Plata, comúnmente llamada área "sur andina", corresponde al centro-sur o Circum Titicaca, que integran el sur del Perú, Bolivia, el norte de Chile y el noroeste de Argentina. En ella la cordillera de los Andes se caracteriza por el Altiplano o Meseta del Collao, destacando la gran meseta central de Bolivia, y, por la costa, el Gran

Cultura Económica. Sebastian, S. 2007. El Barroco Iberoamericano: Madrid: Ediciones Encuentro.

2 El presente trabajo de investigación ha sido posible gracias al apoyo del Consejo Nacional de Investigación Científica y Tecnológica del Estado de Chile que aprobó el proyecto FONDECYT regular N1260 1120562.

${ }^{3}$ López Beltrán, C. 2004. "Los circuitos del comercio colonial en Charcas (hoy Bolivia)", en H. Silva (ed.), Los caminos del MERCOSUR. Historia Económica Regional. Etapa colonial: 33-54. México: Instituto Panamericano de Geografía e Historia. 
Desierto del Pacífico, el que desde el sur del Perú tiene en el tramo chileno de Atacama el hábitat más árido del planeta. Con condiciones naturales extremas, esta área geográfica ha sido escenario de desarrollos culturales que fueron creativos y exitosos para subsistir y progresar en un medio adverso, practicando la movilidad y la trashumancia para el aprovechamiento de los recursos de los distintos pisos ecológicos. ${ }^{4}$

Los valles bajos, situados entre los 0 y los $1.900 \mathrm{msnm}$, son pequeños oasis gracias a los cursos de agua originados en las cumbres del altiplano y las vertientes de precordillera, generando cuencas y reservas naturales. La precordillera o sierra es una reserva natural y cultural en el borde del Desierto, cuya morfología es de cerros y quebradas que se originan en la Cordillera de los Andes, con altitudes entre los 2.000 y los $3.500 \mathrm{msnm}$. Posee clima desértico de altura, con alta radiación y oscilación térmica, aunque en rangos menores que en el altiplano. Gracias a las lluvias estivales la zona es rica en recursos hídricos que afloran como vertientes y alimentan las cuencas de la región, lo que permite el desarrollo de una gran variedad de flora y fauna nativa. El altiplano, situado sobre los $3.600 \mathrm{msnm}$, llamado también meseta del Titicaca, es una planicie de altura, extensa. Se trata de un complejo de cuencas endorreicas, entre las que destaca el conjunto: Titicaca, Desaguadero, Poopó y salar de Coipasa. ${ }^{5}$

La cordillera de los Andes se ensancha en esta zona y genera una gran meseta, caracterizada por una baja presión atmosférica y escasa presencia de oxígeno, con clima de estepa de altura, frío, fuerte radiación solar y amplia oscilación térmica. Durante los meses de diciembre a marzo la zona recibe las lluvias estivales que vienen desde el Atlántico y el Amazonas, las que permiten una gran biodiversidad.

Tiwanaku (1.500 a.C) fue el gran corazón cultural del altiplano que se expandió por la sierra, costa y parte del altiplano central. La cultura aymará y sus etnias Carangas, Lupaca, Pacaje, Urus o Chipayas, entre otras, habitaron el altiplano central estableciendo colonias en los pisos ecológicos inferiores para complementar productos y dieta alimenticia. Luego el Inca extendió su imperio en el siglo XV, hasta la llegada del español en el siglo XVI.

El descubrimiento del mineral de plata de Potosí, en 1545, activó una gran ruta comercial que aprovechó los antiguos caminos prehispánicos. Recuas de mulas y llamas recorrieron las antiguas vías incaicas trayendo el azogue desde Huancavelica y la plata desde Potosí,

${ }^{4}$ Fundación Altiplano (ed.). 2012. Iglesias Andinas de Arica y Parinacota, las Huellas de la Ruta de la Plata: Santiago: Quadgraphics: 25.

${ }^{5}$ Ibídem. 
comunicando las grandes urbes coloniales tales como Cuzco, Arequipa, La Paz y Sucre, irradiando en los poblados andinos -en su camino hacia el puerto de Arica- los estilos artísticos y constructivos de sus iglesias principales. ${ }^{6}$

Desde Potosí, en términos generales, la ruta tomaba dirección sur por el barrio de Cantumarca hacia Porco; desde ahí se encaminaba a la Estancia Chaquilla y el camino avanzaba serpenteando por la Cordillera de los Frailes. Más adelante el Camino Real encontraba el sendero que venía desde las minas de Salinas de García Mendoza en el río Mulato, siguiendo dirección a Belén de Andamarca, cerca del cual, en el siglo XVIII, un arriero construyó el santuario de Copacabana de Andamarca inspirado por un milagro de la Virgen de Copacabana. Desde allí se seguía hacia Opoqueri en dirección noroeste, pasando por Turco hasta Cosapa. Bordeando los pies del volcán Sajama, a $25 \mathrm{k}$. al este, se llegaba a Laguna y luego el paso de Tambo Quemado (actual frontera entre Bolivia y Chile). A continuación se llegaba a la laguna Chungará al pie de los volcanes Payachatas, desde donde se accede al pueblo de Parinacota.

Desde el cercano pueblo de Chucullo, se podía bajar hasta Arica por dos senderos diferentes. La senda norte llegaba a Putre y, recorriendo otros 35 kilómetros, a Socoroma. Abandonando Socoroma se iniciaba, hacia el este, la dificultosa travesía de la zona desértica: la Cuesta Blanca. La ruta atravesaba este desierto hasta caer en el valle de Lluta, cerca del actual pueblo de Poconchile, en el antiguo tambo de Huanta. Este tramo fue también camino incaico. Desde ahí hasta la costa se tomaba dirección sur para acceder al puerto de Arica.

La segunda ruta mencionada tomaba dirección sur hasta Belén y se dirigía a la costa por el valle de la quebrada del río San José, pasando por los pueblos de Livílcar, el santuario de Las Peñas, Molinos, Humagata, hasta San Miguel de Azapa, para desde allí llegar al puerto de Arica. La Ruta descendía hacia la costa entre los cursos altos de los dos ríos de Lluta y Azapa, y podía desviarse a uno u otro valle dependiendo del clima. ${ }^{7}$

Mediante las disposiciones del virrey Toledo (1570), la administración española instauró el sistema de reducciones para el sometimiento y evangelización de las comunidades indígenas en torno a esta gran ruta comercial. Para la atención espiritual se asentaron las

${ }^{6}$ Moreno, R. y Pereira, M. 2011. La Iglesia en la Ruta de la Plata: Viña del Mar: Ediciones Altazor.

${ }^{7}$ López Beltrán, C. 1990. Potosi-Arica, trazado de un recorrido: La Paz: manuscrito inédito. 
órdenes religiosas. Entre ellas hospitalarios, mercedarios, franciscanos, jesuitas y dominicos en la zona costera y en el altiplano. En el último tramo de la Ruta, los agustinos, particularmente en la zona de Oruro, desarrollaron una activa misión.

El obispado de Cusco, fundado en 1537, abarcó las doctrinas y curatos del gran virreinato peruano. De este amplio territorio se desmembraron en 1552, 1605 y 1609, los Obispados de la Plata, La Paz y Arequipa, los que tendrán bajo su jurisdicción las doctrinas que atendían los pueblos en la Ruta de la Plata. ${ }^{8}$

\section{LAS FUENTES Y EL PLANTEAMIENTO DEL PROBLEMA}

En esta ruta se conservan cuatro iglesias con su programa de pinturas murales en buenas condiciones: Copacabana de Andamarca y Curahuara de Carangas en Bolivia y Parinacota y Pachama en Chile. Las pinturas murales ofrecen una mayor certeza de estar analizando un conjunto de imágenes tal como fueron concebidas en los siglos XVII o $\mathrm{XVIII}$, constituyéndose en fuentes válidas para intentar reconstruir esta interacción entre las imágenes y las palabras en la forma como se pudo dar en el período colonial. ${ }^{9}$ Las fuentes escritas seleccionadas para este estudio son los documentos resultantes del Tercer Concilio Limense, especialmente el Catecismo Menor ${ }^{10}$ y el Tercero Catecismo por Sermones ${ }^{11}$ se trata de textos cuya utilización fue propuesta por el Concilio a los sacerdotes que ejercían su ministerio entre indígenas, razón por la cual se presentan en ediciones trilingües o bilingües: castellano, quechua y aymara, o castellano y quechua. ${ }^{12} \mathrm{El}$ concilio ordenaba el uso del catecismo en las parroquias de indios, tal como lo

8 Mesa, José y Gisbert, Teresa, 2003. Historia de Bolivia: La Paz: Editorial Gisbert: 158, 179. Barriga, Víctor. 1952. Memorias para la Historia de Arequipa: Tomo IV, Arequipa: Imprenta Portugal: 60.

9 Gisbert, T. 1992. "La pintura mural andina". Colonial Latin American Review 1: 1-109.

${ }^{10}$ Catecismo Breve para los rudos y ocupados, en Doctrina Christiana y catecismo para instrucciones de los indios, y de las demás personas que deben ser enseñadas en nuestra Santa Fe. 1584. Lima: Antonio Ricardo impresor.

${ }^{11}$ Tercero Catecismo y exposición de la doctrina cristiana por sermones, para que los curas y otros ministros prediquen y enseñen a los indios y a las demás personas: 1773 [1584]. Lima.

12 El catecismo como resumen de la doctrina cristiana tiene dos antecedentes en la Edad Media: los septenarios y los Ars Praedicandi. Los catecismos mayor y menor, emanados del III Concilio Limense, siguen la estructura de preguntas y respuestas del Katechismus in Frag und Antwort de Althamer, publicado en Nüremberg el año 1528. Posteriormente, los catecismos de Lutero (1529), san Pedro Canisio (1555-1559) y el catecismo romano o Catechismus ad parochos (1566) seguirán la misma forma del publicado por Althamer. 
expresa uno de sus decretos: "Praecepit ergo sancta Synodus ómnibus Indorum Párochis in virtute sanctae obedientiae et sub poena excommunicationis, ut catecismo hoc auctoritate ipsius edito quibus úque aliis exclusis usantur et fecundum eum plebem tibi commissan instruere curent". ${ }^{13}$ El uso del sermonario, por el contrario, no fue obligatorio, como se aclara en su proemio: "estos sermones no son cosa de obligación, como lo es el Catecismo, sino de pura voluntad". ${ }^{14}$ Si bien no eran los únicos textos disponibles, se trata de aquellos que tuvieron la más amplia difusión entre doctrineros de indios durante todo el período colonial. ${ }^{15} \mathrm{~A}$ pesar de haber sido publicados en Lima a finales del siglo XVI, mantuvieron su vigencia durante los siglos XVII y XVIII; una manifestación de ello es el hecho de que el VI Concilio Limense, realizado el año 1773, reitera la necesidad de usar los catecismos publicados en 1584 y ordena la reimpresión del Tercero Catecismo por Sermones. ${ }^{16}$ Por su parte, el Sínodo de la Plata de 1772-1773, recomienda usar el resumen de la doctrina cristiana redactado por el mismo sínodo o cualquier "otra cartilla aprobada", ${ }^{17}$ como lo eran -de manera muy especial- los catecismos limenses y el Catecismo para los párrocos, fruto del Concilio de Trento. $^{18}$ Sin duda, las políticas de catequesis no permanecieron inalterables, prueba de ello es la promoción del uso del castellano en desmedro de las lenguas indígenas en la segunda mitad del siglo XVIII, sin embargo, todo indicaría que en la selección y ordenamiento de los contenidos doctrinales los textos derivados del III Concilio Limense mantuvieron su vigencia hasta finales del siglo XIX.19

13 Decreto del Santo Concilio Provincial de Lima, en Doctrina Christiana... 1584

14 Tercero Catecismo... 1773 [1584]: 5.

${ }^{15}$ No es posible conocer con exactitud cuál fue el nivel de cumplimiento de la norma conciliar en relación con el uso del catecismo. Lo cierto es que hay suficientes antecedentes que confirman que su circulación y utilización fue intensiva. Durán, J. G. 1984. Monumenta catechetica hispanoamericana: 337, 340, 443 y 444 Buenos Aires: Facultad de Teología de la Pontificia Universidad Católica Argentina, Santa María de los Buenos Aires. Lisi, F. L. 1990. El tercer concilio limense y la aculturación de los indígenas sudamericanos: 53 Salamanca: Ediciones Universidad de Salamanca. Rodríguez Valencia, V. 1957. El patronato regio de Indias y la Santa Sede en Santo Toribio de Mogrovejo (1581-1606): Roma: Iglesia Nacional Española: 67-71.

16 Vargas, R. 1951-1954, Vargas, R. 1951-1954. Concilios Limenses (1551-1772) : Madrid: Editorial Dykinson: Tomo II : 19-21.

17 Constituciones sinodales del Arzobispado de la Plata. 1854 [17721773]. Argandoña P. M., ed.: Cochabamba: Imprenta de los Amigos: 58.

18 Catecismo del Santo Concilio de Trento para los párrocos. 1782 [1584]. Valencia: Benito Monfort.

${ }^{19}$ Mujica Pinilla recuerda que los catecismos limenses y el confesionario estuvieron vigentes hasta el Concilio Plenario Latinoamericano de 1899. Mujica 
A pesar de la delimitación de las fuentes, el problema sigue siendo suficientemente amplio como para requerir una selección de las temáticas a abordar. En primer lugar, se ha decidido concentrar el estudio en algunos aspectos doctrinales y morales, privilegiando lo que se podrían denominar los temas más recurrentes en los programas pictóricos analizados y que, por tanto, podrían haberse considerado nucleares en la exposición de las verdades cristianas, ya sea por su importancia intrínseca en el edificio intelectual de la teología o por la necesidad del público al que se dirige el mensaje de enfatizar determinados aspectos. Una primera revisión de los textos y las pinturas permite concluir que se considera fundamental acentuar tres elementos de la doctrina de la Iglesia: la vida eterna en su dinámica de salvación y condenación, la redención obrada por Cristo y la comprensión de los sacramentos como canales de las gracias de Dios. ${ }^{20}$ Desde el punto de vista moral se puede afirmar que los textos y las imágenes coinciden en la necesidad de enfatizar las referencias a los pecados de idolatría, superstición, borrachera y fornicación. ${ }^{21}$ En lo ascético se puede observar una insistencia en la vida penitente, presentada a través de santos cuyas vidas se caracterizaron por sus ayunos y mortificaciones. Se trata, en definitiva, de un programa coherente que conecta lo doctrinal, lo moral y lo ascético, cuyo objetivo es grabar en la mente de los fieles que, para ser un buen cristiano y llegar al cielo, se requiere evitar el pecado, llevar una vida de penitencia y participar de los sacramentos.

El análisis, como se puede deducir, se centra en el carácter representativo de las imágenes, lo cual no significa desconocer la relevancia de reflexionar en torno a sus cualidades taumatúrgicas o hierofánicas. Tal como lo plantea Jaime Valenzuela, durante el período colonial "signo y significado tendieron a confundirse, haciendo que la imagen se fundiera con su referente divino y terminara siendo percibida y vivida- como una verdadera presencia divina". ${ }^{22}$ Se trata de lo que Hans Belting identifica como la incapacidad de los teólogos para controlar las imágenes, se les rebelan y adquieren un poder autónomo,

Pinilla, R. 2002. "El arte y los sermones", en El Barroco Peruano. Lima: Banco de Crédito: 222.

${ }^{20}$ Es interesante constatar que la "Summa de la Fe" propone cuatro aspectos como los que todo cristiano debe conocer: la vida eterna, la Trinidad, la salvación obrada por Cristo y la Iglesia, y los sacramentos como instrumentos de salvación. Doctrina Christiana... 1584.

${ }^{21}$ Confessionario, en Ibídem: $6 r-15$.

${ }^{22}$ Valenzuela, J. 2006. "Ambigüedades de la imagen en la cristianización del Perú. Trento, los jesuitas y el Tercer Concilio". Investigaciones Sociales año X No 17: 494. 
porque satisfacen necesidades a las que la Iglesia no llega. ${ }^{23} \mathrm{El}$ texto del Tercero Catecismo deja entrever que sus redactores son conscientes de los riesgos; al prescribir el deber de honrar las imágenes advierte que se debe hacer "no por lo que ellas son en sí, que son de palo, o metal, o pintura, sino por lo que representan". ${ }^{24}$ Sin embargo, la necesidad de estudiar el método de evangelización y catequesis requiere aislar el objeto de estudio de otras realidades con las cuales debe convivir. Al mismo tiempo, se debe tener en cuenta que, al menos en la América colonial, la sacralización de la imagen ocurre con mucha mayor frecuencia en esculturas o en objetos que detentan el carácter de reliquia, rara vez en pinturas sobre lienzo y casi nunca en elementos que, como las pinturas murales, forman parte del edificio de la iglesia.

\section{CATEQUESIS Y CRISTIANIZACIÓN DE LA MEMORIA}

El objetivo es, por tanto, precisar la forma en que se articularon los tres elementos en juego: palabra escuchada, palabra memorizada, imagen observada y recordada. Se debe descartar la posibilidad de que operaran sin una lógica preestablecida; palabras e imágenes entregadas a encontrarse azarosamente según las circunstancias y disposiciones de cada individuo, parece un desperdicio de energías frente a un objetivo complejo de alcanzar: hacer de los indios auténticos cristianos. La primera articulación conocida es la que sitúa a la imagen como ilustración inmediata del sermón o de la catequesis; por ejemplo, el fraile o cura que se detenía en Parinacota tenía un pequeño ciclo de la Pasión que le permitía hablar del misterio de la Redención apoyado en esas imágenes; el sacerdote que predicaba en Copacabana de Andamarca acerca de la bienaventuranza eterna estaba inmerso en un hermoso vergel que representa un sensorial paraíso con sus frondosos árboles, su diversidad de flores y sus pájaros multicolores; el párroco de Curahuara de Carangas que veía la necesidad de predicar acerca de los vicios de la carne, podía sugerir a sus feligreses que mirasen el castigo que les espera a los libidinosos y a los adúlteros en el infierno. Las fuentes dan cuenta de que esto operaba efectivamente de este modo; el predicador sabía que uno de sus recursos era invitar a los feligreses a mirar las imágenes, reforzando así el mensaje que se proponía transmitir. El catecismo limense especifica en este sentido que la doctrina debe ser estudiada en la iglesia "recitándolo a sus tiempos los muchachos y los mayores, quando se junten en la Iglesia", ${ }^{25}$ es decir, frente a las imágenes; por su parte, en el sermonario se pueden encontrar referencias explícitas a las pinturas como la del XXX sermón: "Y por eso

${ }^{23}$ Belting, H. 2009. Imagen y culto. Una historia de la imagen anterior a la era del arte. Madrid: Editorial Akal: 9.

24 Tercero Catecismo... 1773 [1584]: Sermón VIII: 97.

${ }^{25}$ Epístola del Concilio. Doctrina Christiana... 1584. 
habéis visto pintado a San Miguel con un peso, que está pesando a las almas". ${ }^{26}$

Gruzinski al referirse a la función pedagógica y la función mnemotécnica de las imágenes nombra a los franciscanos Jacobo de Testera y Diego Valadés, ${ }^{27}$ activos en Nueva España durante el siglo $\mathrm{XVI}$; los métodos propuestos por los dos frailes, junto con testimoniar el uso temprano de las imágenes en la catequesis americana, confirman que los predicadores naturalmente concebían un sistema de interacción entre palabras y representaciones pictóricas o escultóricas, aunque no siempre lo hicieran con la precisión que propone Valadés en su Rethórica Christiana. ${ }^{28}$ Gruzinski no se detiene a analizar los procesos que las imágenes buscaban producir en la imaginación y la memoria de los indígenas cuando no estaban en la iglesia; no sólo en la dimensión más simple que sería la de servirse de las imágenes para repasar las formulas del catecismo o las palabras del sacerdote, dinámica que debió tener especial importancia en comunidades carentes de atención sacerdotal permanente como Parinacota. Lo que se propone es considerar que el aspecto más relevante en la eficacia de las imágenes es lo que ocurre con ellas cuando no se las está viendo, la persistencia de ellas y su permanente interacción con las palabras. La catequesis para ser eficaz debe activarse en la conciencia del pastor mientras cuida sus llamas en el bofedal o de la mujer que está preparando una watia. Las imágenes del infierno, de los santos y de Cristo crucificado deben permanecer en la memoria de los fieles, articulándose con las palabras del sermón y las formulas del catecismo, tal como lo sugiere este mismo al indicar que los indios deben recitar lo aprendido "aún quando van a sus labores y otras ocupaciones, como en algunas partes muchos buenos indios lo hazen". ${ }^{29}$ Estenssoro, al analizar representación del pecado en forma de sapos, incursiona en este ámbito, identificando algunas de las consecuencias que este entrecruzamiento de palabras e imágenes pudo producir en la imaginación y el comportamiento de los indios. ${ }^{30}$ Schmitt destaca precisamente, en su artículo "La culture de l'imago", la necesidad de ocuparse de "les images mentales, les productions immatérielle et evanescentes de l'imaginaire, de la mémoire, du rêve". ${ }^{31}$ El Tercero Catecismo, siguiendo un criterio del Segundo

${ }^{26}$ Tercero Catecismo... 1773 [1584]: 461.

27 Gruzinski, S. 1991: 75.

${ }^{28}$ Valadés, Fray Diego de. 1579. Rethorica Christiana: Perugia.

${ }^{29}$ Epístola del Concilio. Doctrina Christiana... 1584.

30 Estenssoro, J.C. 2001. "El simio de Dios. Los indígenas y la Iglesia frente a la evangelización del Perú, siglos XV-XVII". Bulletin Institute Français d' études andines 30: 455-474 y 465-471.

${ }^{31}$ Schmitt, J.C. 1996. "La culture de l'imago". Annales 1: 3-36: 4. El autor insiste en la necesidad de considerar en el análisis o lectura de las imágenes esta dimensión vinculada a la imaginatio y la memoria como un aspecto 
Concilio Limense, ${ }^{32}$ recomienda la observación periódica de las pinturas y esculturas: "yd a las yglesias por las mañanas, y allí hazed oración cada día, sin faltar ninguno y también a las tardes, tomando agua bendita y besando la cruz, y mirando las imágenes"; ${ }^{33}$ práctica que se habría concebido con el objetivo de almacenar en la memoria un repertorio iconográfico que se podía activar en el momento en que las circunstancias lo requerían. De este manera, las imágenes y las formulas, como contenedores de memoria, ${ }^{34}$ deben liberar su contenido e interactuar en forma dinámica con la vida real.

\section{LOS CUATRO PROGRAMAS ICONOGRÁFICOS}

Una primera cuestión que se debe tener en cuenta es que los cuatro programas iconográficos en estudio son marcadamente diferentes. Se puede afirmar que las pinturas murales de Parinacota ${ }^{35}$ presentan un claro sentido de exposición de la doctrina, casi como si fuera un

fundamental del imaginario cultural en Schmitt, J.C. 1992. "Imago: de l'image a l'imaginaire", en Baschet, J., y Schmitt, J.C. (dirs.)1996. L'image, Fonctions et usages des images dans l'Occident médiéval. Actes du 6e 'International Workshop on Medieval Societies. Erice, Sicile, 17-23 octobre 1992: 29-57 Paris: 37. Una idea semejante también sostiene en "Images". Dictionnaire Raisonné de l'Occident Médiéval: 499, y también en "L' historien et les images", en Schmitt, J.C. 2002. Le corps des Images. Essais sur la culture visuelle au Moyen Age, 53-54 Paris: Gallimard. El interés de recoger las reflexiones de Schmitt para comprender el uso de las imágenes en el contexto estudiado ya fue adelantado por Castro N., Chacama J. y Mir R. 2009. "Excitar y subyugar. Pastoral de la imagen y poblaciones indígenas en Arica Colonial". Diálogo Andino 34: 25-43: 26.

32 En el sumario del Tercer Concilio Limense se recogen algunas disposiciones del Segundo Concilio Limense, en una de ellas se señala la necesidad de promover entre los indios la asistencia diaria a la iglesia. Tercer Concilio Limense, 1582-1583: 1982: 171 Lima: Facultad Pontificia y Civil de Teología de Lima.

${ }^{33}$ Tercero Catecismo... 1773 [1584]: Sermón XXVIII: 409.

${ }^{34}$ La expresión "contenedores de memoria" pretende abarcar todas aquellas prácticas culturales cuya función es preservar información valiosa para la sobrevivencia de una comunidad.

${ }^{35}$ Briones L. y Villaseca P. 1984. Pintura Religiosa en Tarapacá. Fe y color en el desierto: Chile: Ed. Cabo de Hornos Ltda. Castro, N., Chacama, J. y Mir, R. 2009: 25-43. Chacama, J. 2009. "Imágenes y palabras, dos textos de un discurso: La prédica pastoral en los Andes coloniales. Doctrina de Codpa (Altos de Arica), siglo XVIII". Diálogo Andino 33: 7-29. Corti, P., Guzmán, F. y Pereira, M. 2009. "El Juicio Final de Parinacota", en Campos, N. (ed.) Entre cielos e infiernos, V Encuentro Internacional sobre Barroco, 115-124 La Paz: Unión Latina, Griso y Fundación Visión Cultural. Corti, P., Guzmán, F. y Pereira, M. 2009. "La Pintura Mural de la Iglesia de San Santiago de Curahuara de Carangas como Patrón Iconográfico de la Iglesia de la Natividad de Parinacota", en Campos N. (ed). 2009. 
catecismo pintado, una biblia pauperum contenida en los muros de la iglesia. ${ }^{36}$ Curahuara de Carangas presenta un programa mixto en el que conviven aspectos doctrinales con otros devocionales o ascéticos. ${ }^{37}$ Las pinturas de Pachama son un repertorio de santos, siendo su carácter catequético más bien escaso. Copacabana de Andamarca, finalmente, es un caso bastante excepcional; se podría decir que el único tema es la vida eterna y las postrimerías, con un asombroso énfasis en la representación del paraíso que ocupa casi todos los muros del templo. ${ }^{38}$ Sin duda estas diferencias pueden obedecer a los criterios de los doctrineros, a las devociones particulares de cada comunidad o a las posibilidades físicas que ofrecían las iglesias, más grande o más pequeñas y, por tanto, aptas para recibir una determinada cantidad de imágenes.

No obstante lo anterior, es interesante destacar la congruencia entre el carácter de los programas iconográficos y la diversidad de necesidades de la feligresía que asiste a cada una de las iglesias señaladas. Parinacota es una localidad carente de atención sacerdotal permanente, ${ }^{39}$ la prédica, la enseñanza del catecismo y el acceso a los sacramentos dependen de la esporádica visita del párroco de Codpa o Belén, ambos pueblos ubicados a una gran distancia de Parinacota. ${ }^{40} \mathrm{El}$ año 1739 el obispo de Arequipa constata la amplitud del territorio atendido desde Codpa, la inexistencia de información acerca de las personas que viven en cada pueblo y que, además, el cura está imposibilitado de moverse por su edad y enfermedades. ${ }^{41}$ Es probable que durante largos períodos la única instrucción religiosa la recibiesen de frailes de paso que paraban a reponer fuerzas para continuar viaje hacia la costa o en dirección a las tierras altas. Esta carencia explicaría el énfasis doctrinal de la iglesia; las pinturas debían mantener viva las enseñanzas del último sermón y frescas en la memoria las fórmulas del catecismo. Las pinturas de Pachama fueron pintadas a fines del siglo

36 Corti, P., Guzmán, F. y Pereira, M. 2013. La pintura mural de Parinacota, en el último bofedal de la ruta de la plata: 67-93 Arica, Fundación Altiplano-Universidad Adolfo Ibáñez.

${ }^{37}$ Gisbert T. 2008. "La Iglesia de Curahuara de Carangas", en La Iglesia de Curahura de Carangas: 41-55. La Paz: Plural Editores. Gisbert, T. 1998. Pintura mural en el área centro sur andina: La Paz: Ministerio de Educación, Cultura y Deporte-Organización de los Estados Americanos. Corti, P., Guzmán F. y Pereira, M. 2009. "La Pintura Mural...".

${ }^{38}$ Gisbert, T. 1998.

${ }^{39}$ Chacama, J. 2009: 8.

40 La doctrina de Codpa, que atendía todos los altos de Arica, fue establecida en 1660. El año 1777 se fundó la doctrina de Belén con el objeto de prestar una mayor atención a los pueblos cercanos a la quebrada de Lluta. Vid. Moreno, R. y Pereira, M. 2011: 52.

41 Foja 1 de los Autos del Obispo Cavero, Archivo Arzobispal de Arequipa. 
XVIII, cuando el pueblo de Belén -ubicado a pocos kilómetros de distancia- había sido erigido como parroquia, asegurando una atención sacerdotal más regular, de modo que las pinturas podían obviar los contenidos catequéticos y satisfacer necesidades devocionales 0 centrarse en mensajes de contenido ascético. El carácter mixto de Curahuara de Carangas, doctrinal y devocional al mismo tiempo, podría obedecer a que las pinturas más antiguas son de comienzos del siglo $\mathrm{XVII}$, período en el que habría sido necesario un conjunto de imágenes de marcado carácter catequético; su condición de parroquia modificó la situación, los habitantes del pueblo eran formados por el cura, provocando una ampliación o modificación del programa hacia contenidos devocionales o ascéticos. ${ }^{42}$ El caso más sorprendente sería el de las pinturas de Copacabana de Andamarca, de mediados del siglo $\mathrm{XVIII},{ }^{43}$ concentradas en la representación de las postrimerías, con especial énfasis en la bienaventuranza; su carácter de santuario ${ }^{44}$-no era un lugar donde vivieran indios en forma permanente y aún hoy su población es muy reducida- le libera de la obligación de contener un programa doctrinal o ascético más o menos completo; el peregrino estaba en la iglesia unos pocos días, tras los cuales se esperaba que llevara consigo una experiencia religiosa más que un conjunto articulado de enseñanzas. No es un programa de catequesis o, si se quiere, es una propuesta iconográfica que se detiene en un solo aspecto de la doctrina cristiana: el destino eterno del hombre, cuya naturaleza estaría creada para contemplar a Dios y disfrutar de los bienes celestiales. Sería interesante plantear la posibilidad de una relación entre la peregrinación al santuario y la vida de penitencia que conduce a la Jerusalén celestial representada en los muros de la iglesia.

\section{LA VIDA ETERNA}

Es claro que la metodología misional cuenta con las postrimerías como una pieza clave. ${ }^{45}$ Lo anterior se puede deducir de las conocidas

42 Tal como lo señala Teresa Gisbert, "la pintura que decora los muros de la iglesia tiene dos fases, la primera fue hecha poco antes de 1608 y la segunda, que posiblemente rehace los antiguos murales deteriorados, corresponde al año 1777". Gisbert, T. 2008: 44.

${ }^{43}$ La iglesia de Copacabana de Andamarca estuvo a cargo de los Agustinos hasta 1759, la presencia de iconografía agustiniana permitiría pensar que la iglesia y las pinturas son anteriores al año señalado. Por otra parte, sin ser un dato conclusivo, uno de los retablos lleva una inscripción con el año 1754. Gisbert T. y Schauer, P. 2010. Iglesias rurales de La Paz y Oruro: 69 La Paz: Editorial Gisbert. Gisbert, T. 1998: 131.

${ }^{44}$ Schauer, P. y Gisbert T. 2010: 68-69.

45 Mujica Pinilla, R. 2003. "Identidades alegóricas: lecturas iconográficas del barroco al neoclásico", en El Barroco Peruano 2: 251-335. Lima: Banco de Crédito: 278-283. 
referencias del jesuita Bernardo Bitti: " $\mathrm{y}$ a avido notables mudanzas y conversiones de indios con la consideración del juicio y la gloria y penas de los condenados, que está todo pintado por las paredes de esta iglesia y capilla", ${ }^{46}$ así como de las expresiones de Guaman Poma de Ayala: "Y en cada iglesia ayga un juycio pintado. Allí se muestre la venida del Señor al juycio, el cielo y el mundo y las penas del ynfierno, para que sea testigo del cristiano pecador". ${ }^{47}$ Un testimonio más contundente aún surge de la estructura de los catecismos limenses, todos ellos entregan un espacio preponderante a la exposición de las postrimerías, pudiendo afirmarse que el edificio de la doctrina cristiana se sostiene en dos ideas basales: la existencia de un solo Dios y la inmortalidad del alma. No son aspectos centrales de la doctrina, pero son elementos imprescindibles para comprender otros más elevados. En la Summa de la Fe se afirma que el primer punto que todo cristiano debe profesar es: "Que ay un solo Dios, hazedor de todas las cosas. El qual después de esta vida, da gloria eterna a los buenos que le sirven, y pena eterna a los malos que lo ofenden". 48

Escapa al ámbito de este trabajo hacerse cargo de las concepciones de las culturas andinas acerca de la vida después de la muerte; sin embargo, se puede indicar que la extendida costumbre de depositar ofrendas en los entierros, así como la práctica de construir chulpas, es una señal significativa de la creencia en algún tipo de sobrevivencia de los antepasados; ${ }^{49}$ en consonancia, Calancha señala que los pueblos de la sierra creían que "las ánimas de los que mueren van a una tierra que llaman Upamarca" ${ }^{50}$ Lo que sí es posible abordar es la idea que los documentos analizados contienen acerca de este tipo de creencias entre los indígenas. El Tercero Catecismo es bien explícito sobre este punto, dando cuenta de que la difusión de la doctrina cristiana sobre la vida eterna y las postrimerías se topaba con algunas creencias

46 Vega, Antonio de. 1948 [1600]. Historia y narración de las cosas sucedidas en este Colegio de Cuzco desde su fundación hasta hoy, 1 de noviembre día de Todos los Santos, año de 1600: Tomo VI, 42-43 Lima: Biblioteca Histórica Peruana. Instituto de Investigaciones Históricas.

47 Guama Poma de Ayala, Felipe. 2008 [1615]. Nueva Corónica y buen gobierno: Tomo II, 548 Lima: Fondo de Cultura Económica.

48 Summa de la Fe, en Doctrina Christiana... 1584. También es interesante destacar el espacio que la da el sermonario limense a las postrimerías, dedicándole tres sermones, el primero, el trigésimo y el trigésimo primero, en Tercero Catecismo... 1773 [1584]: 1-12, 453-515.

${ }^{49}$ Castro, V. 2009. Evangelización y religión andina en los Andes del sur: 109 Santiago: Fondo de publicaciones americanistas y Centro de Investigaciones Diego Barros Arana. Gisbert, T. 2009. El paraíso de los pájaros parlantes, la imagen del otro en la cultura andina: 3-38 La Paz: Plural Editores.

50 Calancha, Antonio de. 1638. Chronica moralizada del orden de S. Agustín en el Perú, con sucesos exemplares vistos en esta Monarchia: Barcelona, citado en Ibidem: 5. 
ancestrales que ayudarían y otras que entorpecerían la aceptación de la nueva religión. La inmortalidad del alma humana no parecía contar con ningún obstáculo significativo para su asimilación: "y esto así lo entendieron vuestros antepasados, aunque en muchas cosas anduvieron errados y engañados; pero bien atinaron a que había otra vida, y que las ánimas salidas de los cuerpos no se acabaran luego, más vivirán en la otra vida". ${ }^{51}$ Sin embargo, el mismo texto, en uno de los sermones dedicados a las postrimerías, advierte una confusión en los indios respecto de la naturaleza que esta vida supra terrenal tendría: "No penséis que los que tienen en sus entierros mucha ropa, o comida, u oro, o plata, que gozan en la otra vida de cosa de estas, ni aún lo saben. Eso es desatino de vuestros viejos, que como unos muchachos no saben cosa de la otra vida" ${ }^{52}$ El texto advierte acerca del peligro de creer que luego de la muerte prosigue una nueva vida semejante a la actual, idea totalmente disonante con la concepción cristiana de la gloria celestial y las tinieblas infernales, mundos que no se pueden comparar con la existencia terrenal.

El Catecismo Breve retiene en sus fórmulas la inmortalidad del alma y la existencia del premio y el castigo eterno. Los indios de Parinacota, Curahuara de Carangas y Copacabana de Andamarca podrían observar una y otra vez el Juicio Final pintado en los muros de su iglesia, ${ }^{53}$ en esas imágenes veían las almas de los hombres representadas como cuerpos desnudos, haciendo eco de las palabras del trigésimo sermón: "de esta vida miserable ninguna cosa llevan los hombres a la otra vida... Tan pobre y desnudo de todo esto va el Inga, como el Indio hatun luna", enfrentando así la hipótesis de una concepción indígena de una vida posterior a la muerte en la que se come, se bebe y se perpetúan las circunstancias de la vida terrenal. La vida eterna cristiana, por el contrario, transcurre en otro lugar e implica una nueva condición. La idea de la mortalidad del cuerpo y la inmortalidad del alma parece ser otra idea central, expresada nítidamente en el primer sermón del Tercero Catecismo "nuestras almas son inmortales, y no se pueden acabar". ${ }^{54}$ En los habitantes de estas localidades se cruzarían la impactante imagen de muchedumbres de cuerpos desnudos, las palabras del sacerdote en el sermón, con la sintética fórmula del catecismo breve, repetida de memoria una y otra vez: "las ánimas de los hombres no mueren con los cuerpos, como las bestias, mas son inmortales, y nunca se acaban". ${ }^{55}$ Esta frase volvería a su memoria al

51 Tercero Catecismo... 1773 [1584]: Sermón I: 4.

52 Ibídem: Sermón XXX: 456-457.

${ }^{53}$ Corti, P., Guzmán, F. y Pereira, M. 2009. "El Juicio Final...” y Corti, P., Guzmán, F. y Pereira, M. 2009. "La Pintura Mural...”.

54 Tercero Catecismo... 1773 [1584]: 4.

${ }^{55}$ Catecismo Breve para los rudos y ocupados, en Doctrina Christiana... 1584: $14 r$ 
pensar en la muerte, al mirar el Juicio Final de la Iglesia o al atender al sermón del sacerdote.

Las tres pinturas mencionadas son explícitas en mostrar que estos cuerpos desnudos que representan a las almas inmortales se enfrentan a dos destinos bien distintos. En Curahuara y Parinacota se recurre a la solución habitual en la iconografía europea del Juicio Final, los salvos a la derecha de Cristo y los condenados a su izquierda. ${ }^{56}$ La pintura de Copacabana de Andamarca, por el contrario, es un río diagonal de almas cuyo flujo se divide en la mitad en un curso descendente que conduce al infierno y en otro ascendente que lleva al cielo. El trigésimo sermón se detiene a describir el infierno como "un lugar que está en lo profundo de la tierra, todo obscuro y espantable, donde hay cien mil millones de tormentos"; ${ }^{77}$ las tres pinturas murales están en sintonía con esta descripción: el infierno es representado como un lugar caótico y tenebroso, habitado por cuerpos cenicientos que derraman lágrimas de desesperación en medio de suplicios de diversa naturaleza. ${ }^{58} \mathrm{La}$ fórmula del catecismo breve señala: "Los que no creen en lesu Christo y los q aunque tienen fe, no tienen obras, ni guardan su ley, no se salvan. Mas serán condenados a penas eternas del infierno". ${ }^{59}$ El Catecismo Mayor por su parte sentencia: "Después de esta vida ay tormentos y penas sin fin, para los malos, que no sirven a Dios" ${ }^{60}$ No es posible conocer la síntesis que los habitantes de estos poblados realizarían a partir de esta batería de imágenes y palabras que se les proponían, sin embargo, todo parece concebido para que la reflexión sobre el infierno decante en las imágenes de las tinieblas, los castigos, la anarquía y la desesperación perpetua. El carácter tenebroso está presente en los tres murales, destacando la solución de Curahuara de Carangas que muestra al infierno como una sombra siniestra. El sufrimiento sin fin es pintado con mucha eficacia en los muros de Parinacota, donde se puede ver a monstruosos demonios divirtiéndose con los tormentos humillantes que infringen a los condenados. La anarquía, por su parte, queda muy bien plasmada en Andamarca, en cuyos muros se observa un revoltijo de cuerpos cayendo en las fauces del Leviatán, carentes ya de toda humanidad. La imagen de la desesperación se puede encontrar en las actitudes de los condenados pintados en los tres murales; los ríos de lágrimas, las muecas grotescas y los gestos crispados expresan con nitidez la carencia completa de todo horizonte de esperanza. Se puede

56 Gisbert, T. 2008: 44. Corti, P., Guzmán, F. y Pereira, M. 2009. "La Pintura Mural...": 127. Réau, L. 1998. Iconografía del arte cristiano: Tomo 1, Volumen 2, 750 Barcelona: Ediciones del Serbal.

57 Tercero Catecismo... 1773 [1584]: 470.

${ }^{58}$ Réau, L. 1998: 774-775.

${ }^{59}$ Catecismo Breve para los rudos y ocupados, en Doctrina Christiana... 1584: $16 r$

${ }^{60}$ Catecismo Mayor, en Doctrina Christiana... 1584: 26 r. 
afirmar que la principal herramienta para manifestar el horror del infierno son las imágenes pictóricas, en ellas se contienen un sin fin de detalles escabrosos que las palabras no expresan. El temor que producirían las imágenes irá acompañado en la mente de los indígenas por la repetición memorística de las frases del catecismo que, como martillazos, golpeaban sus conciencias mientras salían de sus labios: "tormentos y penas $\sin$ fin, para los malos, que no sirven a Dios". ${ }^{61}$

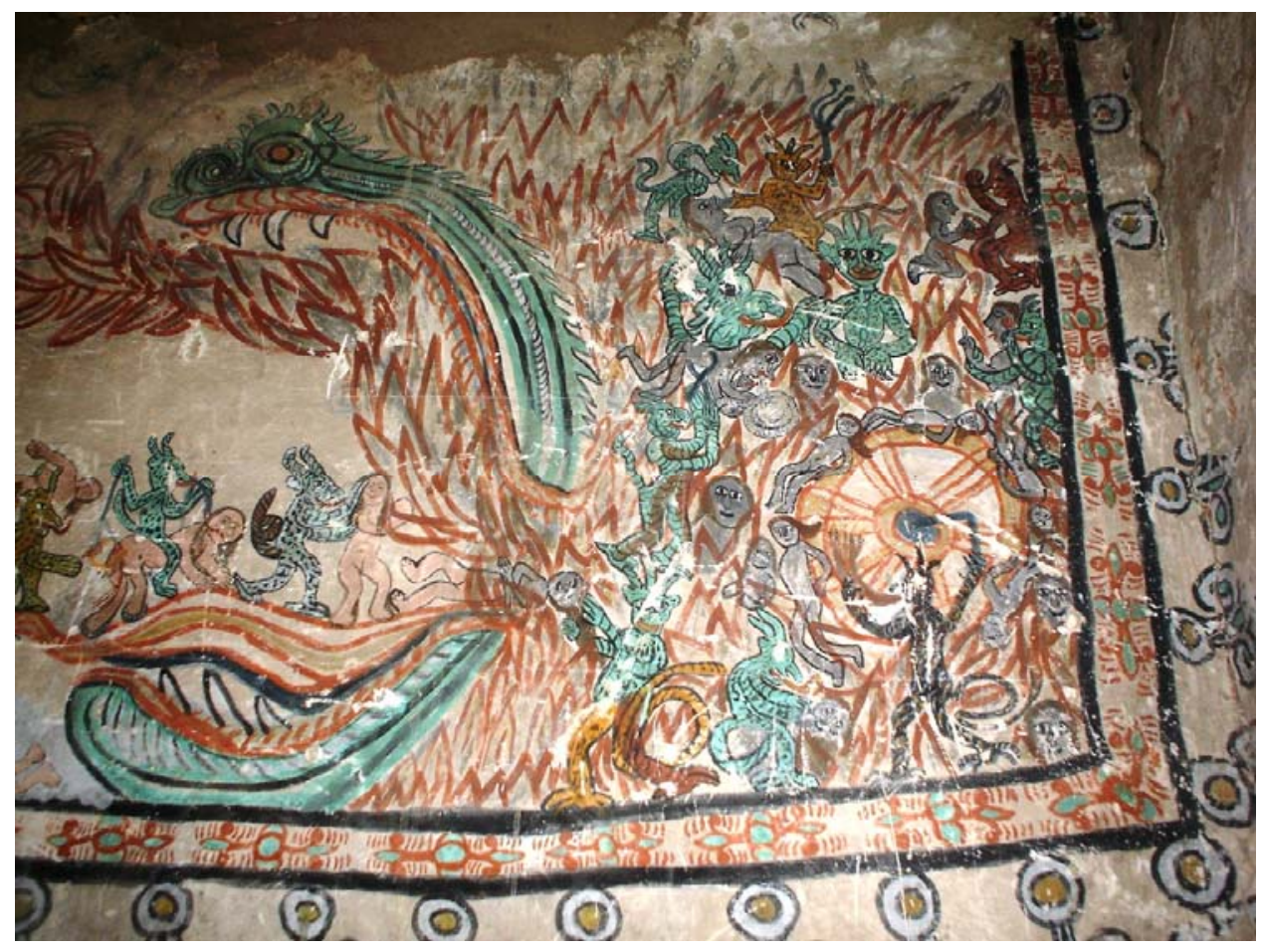

Figura 1. Juicio Final, detalle. Iglesia de la Natividad de Parinacota. Siglo XVIII

${ }^{61}$ Ídem. 


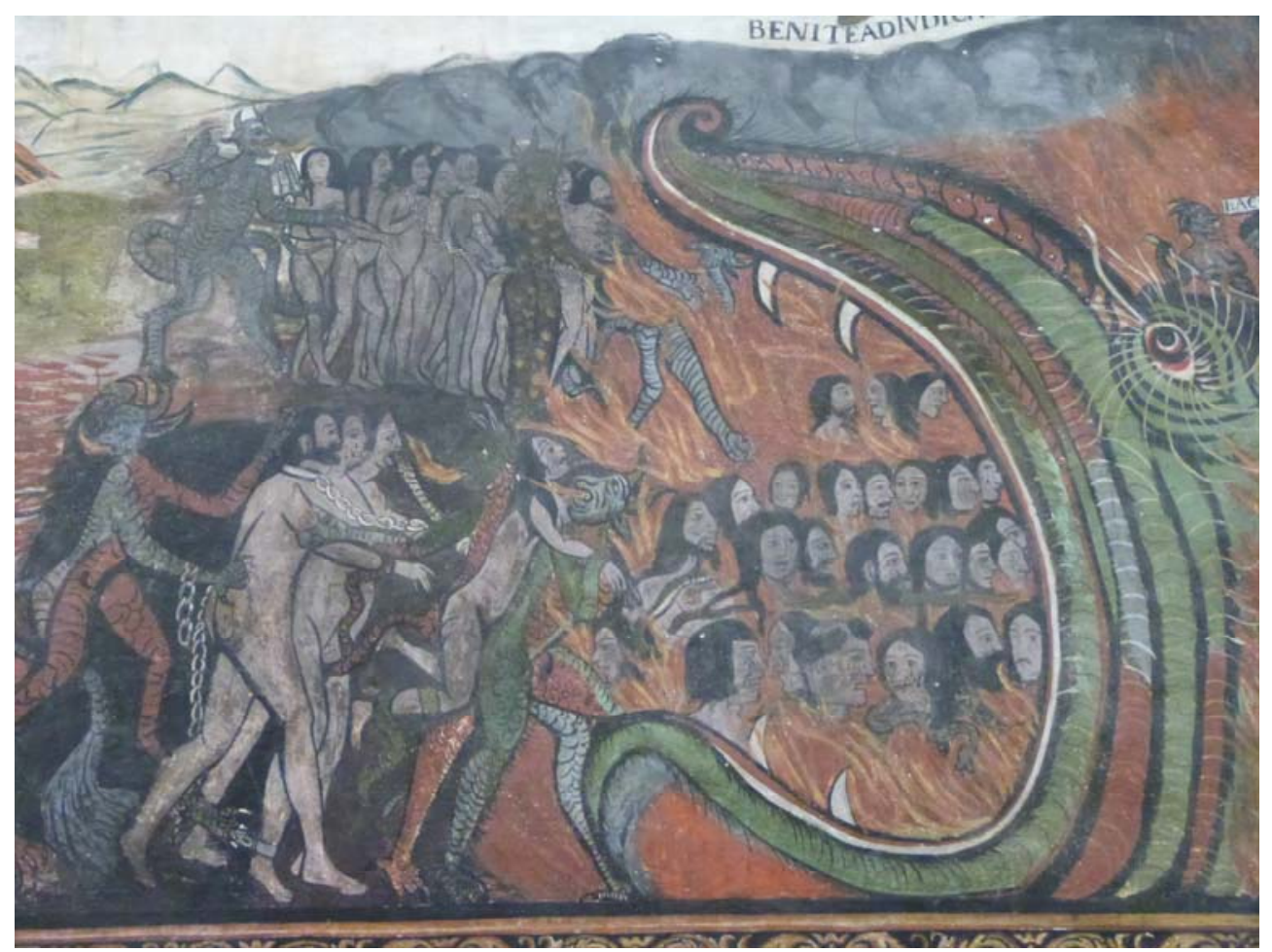

Figura 2. Juicio Final, detalle. Iglesia de Santiago de Curahuara de Carangas. Siglo XVIII.

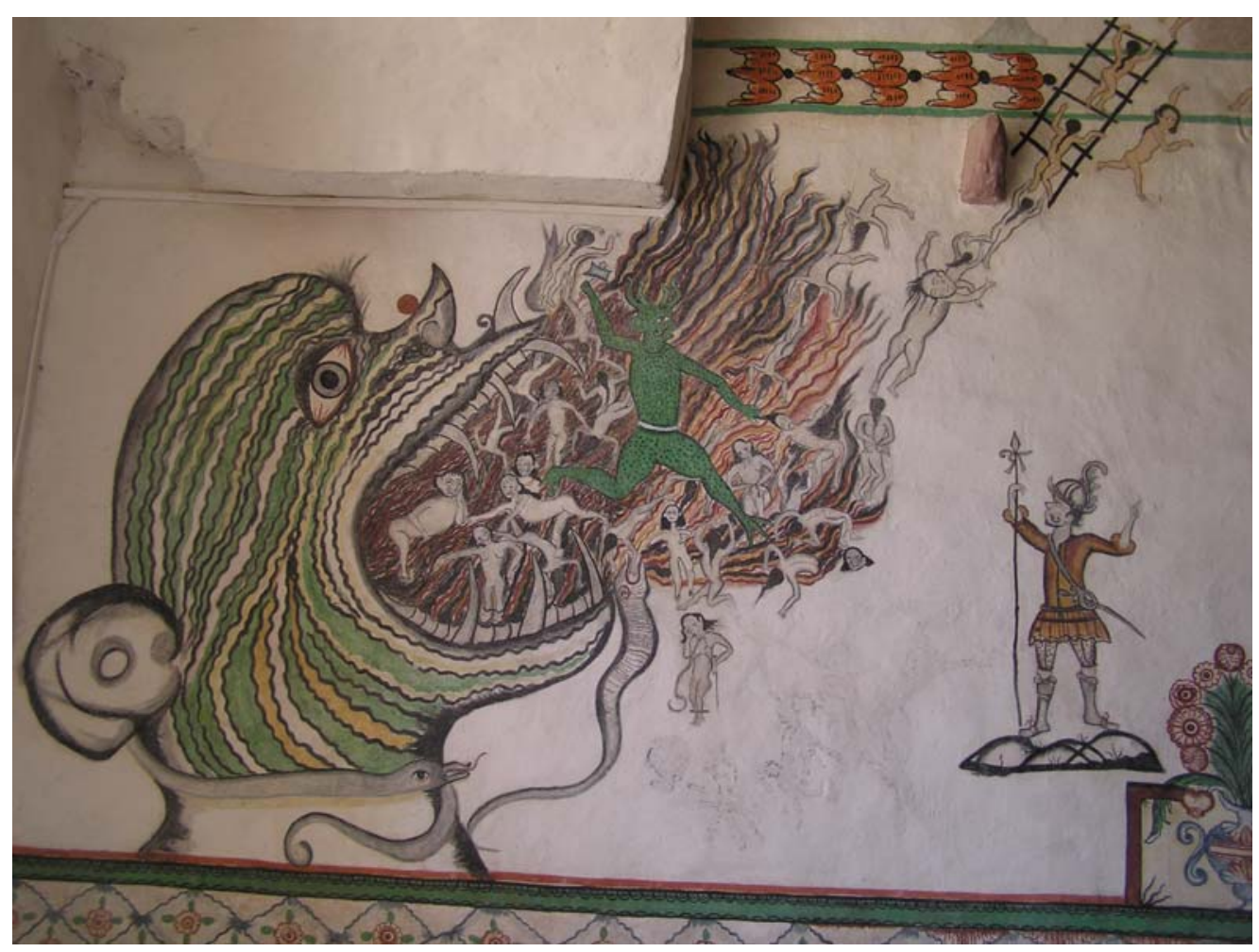

Figura 3. Postrimerías. Iglesia de Nuestra Señora de Copacabana de Andamarca. Siglo XVIII. 
La espectacularidad de las imágenes infernales no siempre está equilibrada con una representación del cielo que le compita adecuadamente. En el Juicio Final de Curahuara de Carangas se puede ver una corte celestial de gran solemnidad, pero carente de vitalidad; en Parinacota el cielo es una imagen secundaria y marcadamente estática. ${ }^{62}$ Tampoco el catecismo es particularmente ilustrativo a la hora de referirse al premio de los que se salvan: "gozarán en cuerpo, y en alma de bienes eternos en el cielo" ${ }^{63}$ El último sermón del Tercero Catecismo termina precisamente con una descripción del cielo en la que más que decir qué es el cielo, se refiere a lo que no es, "que ya no hay hambre, ni enfermedad, ni pobreza, ni cansancio, ni muerte. Ya no hay tristeza, ni cuidado, ni temor ni recelos. Ya no hay enojos, ni envidias, ni contradicción. Ya no hay gemidos, ni angustias, ni tribulaciones. Ya no hay pecados, ni tentaciones, ni mentiras, ni desórdenes, ni escándalos". ${ }^{64}$

A continuación, el sermón describe algunos aspectos del estado de gloria como los prados floridos, la sutileza de los cuerpos, el amor universal y la contemplación de la belleza de Dios, cerrando con la sentencia paulina relativa a la imposibilidad de describir las moradas celestiales: "No se puede esto hermanos pensar como es, y mucho menos se puede decir: porque ni oyó oído, ni vio ojo, ni imaginó pensamiento la grandeza de los bienes que Dios tiene para los que le aman y sirven". ${ }^{65}$ Estas últimas palabras podrían servir de explicación para la relativa parquedad de las imágenes pictóricas del cielo, sobre todo si lo juzgamos a la luz de la espectacularidad de las pinturas de infiernos; lo que no se puede imaginar no se puede traspasar a líneas y colores. El sistema estaría concebido para que los habitantes de los pueblos estudiados miraran a San Pedro flanqueando las puertas del cielo, en el caso de Parinacota, o a San Miguel Arcángel recibiendo a las almas en el paraíso, como se ve en Copacabana de Andamarca, tratando de imaginar la naturaleza de esos "bienes eternos" ${ }^{\text {"6 }}$ que le promete la fórmula del catecismo y que el apóstol Pablo no se atreve a describir, consolándose con la certeza de que al traspasar el portal celeste "ya no hay gemidos, ni angustias, ni tribulaciones". ${ }^{67} \mathrm{La}$ imaginación puede volar libremente para construir los rasgos específicos del premio prometido por Dios, buscando las imágenes más apropiadas

62 Se deben distinguir dos representaciones distintas: el tribunal celestial y la escena de los justos que marchan al cielo. Corti, P., Guzmán, F. y Pereira, M. 2009. "La Pintura Mural...": 129. Réau, L. 1998: 761-766.

${ }^{63}$ Catecismo Breve para los rudos y ocupados, en Doctrina Christiana... 1584: $16 r$.

64 Tercero Catecismo... 1773 [1584]: 512-513.

65 Ibídem: 514-515.

${ }^{66}$ Catecismo Breve para los rudos y ocupados, en Doctrina Christiana... 1584: $16 r$

67 Tercero Catecismo... 1773 [1584]: 513. 
para darle forma. Para Teresa Gisbert las representaciones más cautivantes del cielo tomarían, en el contexto andino, la forma de un jardín exuberante poblado de aves coloridas. ${ }^{68}$ Por tanto, los árboles, flores y frutas que pueblan los muros de la iglesia de Copacabana de Andamarca serían una imagen eficaz para traducir la expresión: "ni oyó oído, ni vio ojo, ni imaginó pensamiento" ${ }^{69}$

\section{PASIÓN DE CRISTO}

En el sermonario y los catecismos limenses la exposición de la doctrina cristiana tiene una secuencia lógica que comienza con la idea de la inmortalidad del alma y la explicación acerca del pecado y sus consecuencias: la degradación humana y la eterna condenación. A continuación, los textos postconciliares se preguntan si existe alguna posibilidad de librarse de los males que el pecado produce: “¿No ay algún remedio para volvernos a la gracia y amista de Dios, y ser librados de muerte eterna?", interroga el Catecismo Mayor, mientras el Tercero Catecismo incoa en su tercer capítulo la repuesta: "Ya os dije, hermanos, en el sermón pasado, la fealdad del pecado, y el daño que nos hace: y sobre todo, quanto enoja a Dios. Ahora os quiero decir el remedio que tenemos los hombres para librarnos del pecado". ${ }^{70}$ Luego, de una forma más sintética en el Catecismo Menor y más desarrollado en el Sermonario se explicita la doctrina de la salvación obrada por Jesucristo, culminando con la referencia a su Pasión como coronación de un proceso cuyo objetivo es reconciliar al hombre con Dios. ${ }^{71}$

Curahuara de Carangas tiene en el Baptisterio un breve ciclo con tres escenas de la Pasión; la pequeña iglesia de Parinacota cuenta con cinco escenas que definen el programa iconográfico de sus murales. La primera pintura, en orden cronológico, sería la "Oración en el Huerto de los Olivos", presente en ambas iglesias, que muestra a Jesús aceptando los signos de la Pasión que un ángel le presenta, mientras los discípulos duermen a su lado. ${ }^{72}$ Por su parte, el sermonario no se detiene en este acontecimiento, pero sí hace énfasis en la idea de que Cristo conocía lo que le ocurriría y que, a pesar de lo anterior, eligió libremente padecer el tormento de la Cruz, señalando: "siendo su voluntad morir, por redimirnos del pecado". ${ }^{73} \mathrm{El}$ sacerdote, luego de pronunciar la formula contenida en el Tercero Catecismo, podría extenderse en el relato de la Oración en el Huerto, sirviéndose para ello de la pintura, reforzando de este modo la

${ }^{68}$ Gisbert, T. 1992: 127.

69 Tercero Catecismo... 1773 [1584]: 515. Gisbert plantea esta asociación: Ídem.

70 Tercero Catecismo... 1773 [1584]: Sermón Tercero: 26.

71 Ibídem: 28.

72 San Lucas 22, 39-43.

73 Tercero Catecismo... 1773 [1584]: Sermón Tercero: 32. 
idea que el texto proponía. El "Prendimiento de Cristo"74 se encuentra sólo en Parinacota; los ojos, y con ellos la memoria de los oyentes, se concentrarían en esta imagen cuando el sacerdote pronunciaba la fórmula: "fue vendido, ... y puesto en manos de sus enemigos". ${ }^{75}$ Luego, mientras se oían las palabras: "fue azotado reciamente", ${ }^{76}$ todos voltearían su rostro o su corazón hacia la imagen que muestra a Cristo atado a una gran columna mientras es flagelado por dos verdugos, ${ }^{77}$ como se puede ver en Curahuara y Parinacota. A continuación, la imagen del Nazareno, pintada en ambas iglesias, se entrelazaría con la expresión "y llevando una cruz sobre sus hombros", produciendo una tensión de particular eficacia. El sintético relato culminaba cuando resonaban las palabras: "fue llevado al monte calvario, y allí fue crucificado, y estuvo tres horas padeciendo grande tormentos, y muchas afrentas de sus enemigos", ${ }^{78}$ tal como se podía ver en la Crucifixión del ciclo de Parinacota y en las dos que se conservan en el templo de Curahuara de Carangas.

${ }^{74}$ Schenone, H. 1992. Iconografía del Arte Colonial, los Santos: 187-202 Buenos Aires: Fundación Tarea. Réau 1998: 452-453.

75 Tercero Catecismo... 1773 [1584]: Sermón III: 32.

76 Ibídem: 33.

${ }^{77}$ Réau, L. 1998: 472.

78 Tercero Catecismo... 1773 [1584]: Sermón III: 33. 


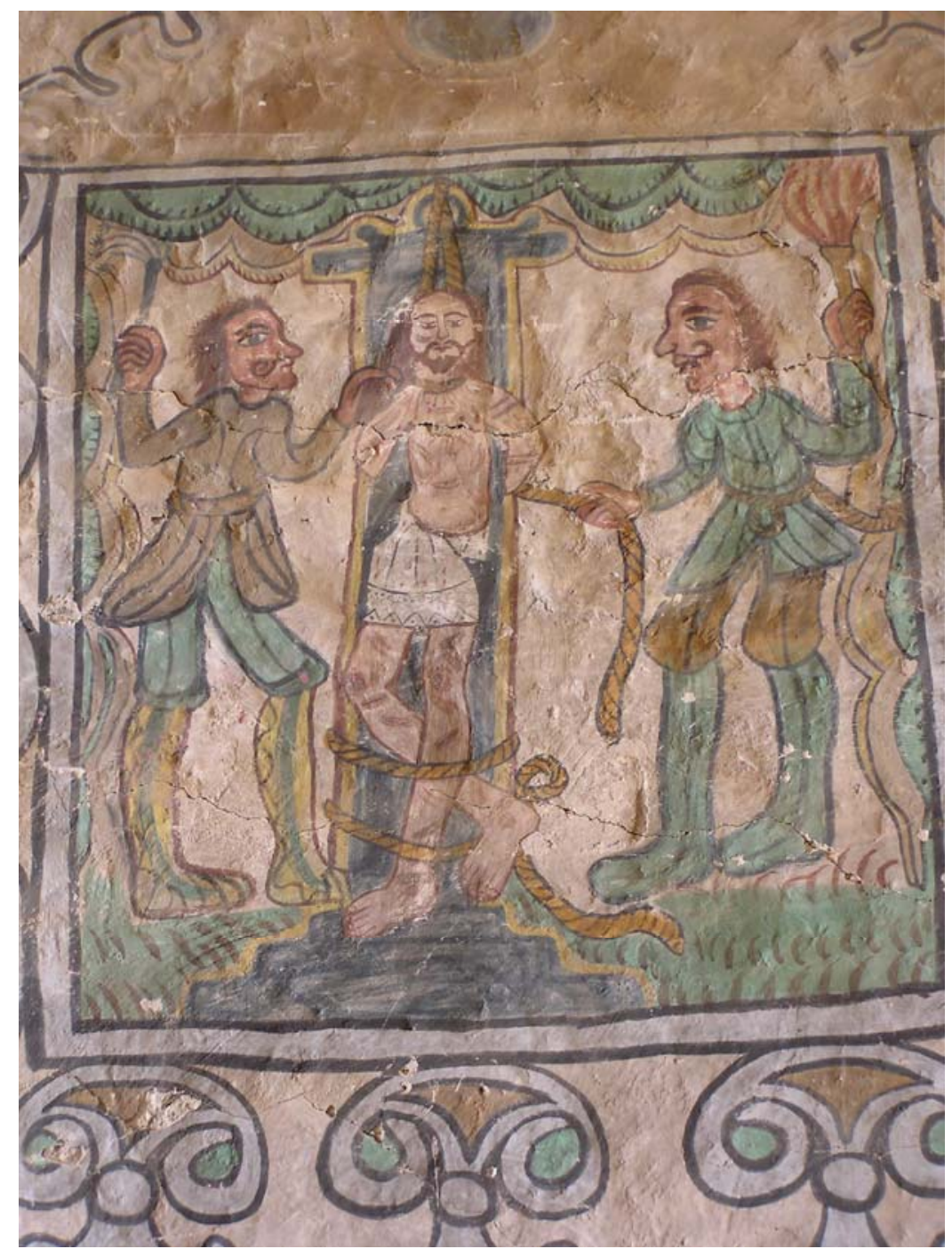

Figura 4. Cristo atado a la columna. Iglesia de la Natividad de Parinacota. Siglo XVIII.

El tercer sermón termina con una llamada explícita a contemplar las imágenes relativas a la pasión, señalando, "mirad en la iglesia la imagen del Crucifijo, e hincadas las rodillas adoradla", ${ }^{79}$ invitando a considerar que Cristo "estuvo en la cruz como aquella imagen os representa", ${ }^{80}$ sacrificio que debe mover a los fieles a la contrición y a acomodar su vida a las enseñanzas de la Iglesia. La escena del calvario, que se encuentra en Curahuara de Carangas sobre uno de los altares laterales del muro de la epístola, representa a dos orantes indígenas, curacas sin duda, que se arrodillan para adorar a Cristo crucificado, haciendo eco del texto del Sermonario. ${ }^{81}$ Con este espíritu de compasión

\footnotetext{
${ }^{79}$ Ibídem: 37.

80 Ídem.

${ }^{81}$ Los curacas representados estarían mencionados en un letrero que se ubica al pie de la pintura, sus nombres son Baltasar Cachagas y Gonzalo Larama. Gisbert, T. 2008: 43.
} 
se deseaba que los indígenas contemplaran las imágenes de Cristo sufriente o escucharan los sermones sobre la pasión.

El diálogo entre el sermón y las pinturas debía complementarse o reforzarse con el recuerdo de las resumidas fórmulas del catecismo. Después de escuchar una homilía sobre la pasión o mientras observaba la representación de la crucifixión, el fiel debía recordar alguna de las sentencias previamente memorizadas; los indios con mejor disposición para el estudio repetirían musitando que Cristo murió "por pagar el pecado del árbol vedado, en el madero de la cruz, y por ponerse adonde todos miremos, y nos salvemos: y por esto la señal de la cruz es señal del christiano", ${ }^{22}$ tal como aparece en el Catecismo Mayor; los indios poco preparados recordarían la formula breve del Catecismo Menor: "murió en la Cruz por librar a los hombres del pecado". ${ }^{83}$

\section{SACRAMENTOS}

"Os diré, hermanos muy amados, lo que habéis de hacer para alcanzar el perdón de vuestros pecados, y salvaros, por Jesu Christo nuestro Señor y Redentor" ${ }^{84}$ Así comienza el cuarto sermón del Tercero Catecismo, recordando que los dones que brotan del sacrificio de la Cruz no se aplican automáticamente; para acceder a ellos se requiere una acción personal. El texto continúa indicando las cuatro cosas que se deben hacer para alcanzar la salvación: creer en Jesucristo, arrepentirse de las faltas cometidas, cumplir los mandamientos y "recibir los sagrados sacramentos, que Él ordenó para remedio de los pecados" ${ }^{85}$ Quienes aprendían las formulas del Catecismo Mayor conectarían este aspecto del cuarto sermón con las dos primeras respuestas de la parte tercera; sobre la naturaleza de los sacramentos repetirían de memoria que son "una señal, y ceremonia exterior, con que los christianos honran a Dios, y mediante ella participan de su gracia, por virtud de la passion de Jesu Chisto", ${ }^{86}$ aseverando luego que fueron instituidos por "El mesmo Jesu Chisto Dios, y Señor nuestro, para nuestro remedio, y salud". ${ }^{87} \mathrm{~A}$ continuación, ambos documentos limenses señalan la necesidad de recibir el Bautismo, de confesarse con frecuencia y de recibir la Eucaristía con la periodicidad que a cada uno indique el sacerdote.

El sacramento del Bautismo, siguiendo la doctrina habitual, se presenta como la puerta de entrada a la Iglesia y condición indispensable para la salvación; "nadie puede ser salvo sin recibir el sancto baptismo

${ }^{82}$ Catecismo Mayor, en Doctrina Christiana... 1584: 38a.

${ }^{83}$ Catecismo Breve para los rudos y ocupados, en Ibídem: 15a-15r.

${ }^{84}$ Tercero Catecismo... 1773 [1584]: Sermón IV: 39.

85 Ibídem: 40.

${ }^{86}$ Catecismo Mayor, en Doctrina Christiana... 1584: 45r.

${ }^{87}$ Catecismo Mayor, en Ibídem: 46a. 
por obra, quando puede, o a lo menos, por desseo, quando no puede por obra", ${ }^{88}$ repetiría el indio catequizado al mirar las pinturas sobre el sacramento que se conservan en Parinacota y Curahuara de Carangas. En ambas iglesias se pintaron escenas del Bautismo de Cristo en el Jordán, con el objeto de poder recordar la teofanía que describen los Evangelios y destacar el ejemplo del Salvador que se somete a un rito que no necesitaba. ${ }^{89}$ La pintura de Parinacota se encuentra en el muro de la epístola, ${ }^{90}$ muy cerca del presbiterio, la del templo boliviano, en cambio, fue realizada en la bóveda del presbiterio; ${ }^{91}$ las soluciones iconográficas no son idénticas, pero presentan los rasgos esenciales del relato; Cristo con las manos en oración recibe el agua que San Juan Bautista vierte sobre su cabeza, mientras el Espíritu Santo en forma de paloma vuela sobre la figura del Redentor. En el Baptisterio de Curahuara de Carangas se pintó la imagen de San Francisco Javier bautizando indios, al centro el santo jesuita con roquete y estola sostiene una escudilla con la que derrama agua sobre la cabeza de un noble inca, mientras otros de su condición esperan turno; a la derecha del patrono de los misioneros se representó a un grupo de curacas que por sus uncus podrían identificarse como señores Carangas. ${ }^{92}$ La observación de estas dos pinturas y la recitación de la respuesta del catecismo provocaría reacciones diversas; quienes estaban bautizados recordarían quizá las palabras del sermón décimo: "los que soys baptizados, alegraos mucho, porque tanto bien alcanzasteis",93 por el contrario, los que no habían recibido el sacramento o sabían de alguien que no lo había hecho, tendrían en su memoria otras palabras del mismo texto: "el que no naciere por agua, y por Espíritu Santo, que es ser baptizado, no entrará jamás en el cielo". ${ }^{94}$ En el techo del Baptisterio de Curahuara de Carangas, justo sobre la pila, hay una gran figura del Espíritu Santo en forma de paloma, representando así, de forma plástica, el invisible descenso del Paráclito sobre el nuevo cristiano. ${ }^{95}$

${ }^{88}$ Catecismo Mayor, en Ibídem: 47r.

${ }^{89}$ Réau, L. 1998: 308-314.

${ }^{90}$ Corti, P., Guzmán, F. y Pereira, M. 2013: 43.

${ }^{91}$ Gisbert, T. 2008: 44.

92 Schenone, H. 1992: 408-416. Gisbert, T. 1998: 152.

93 Tercero Catecismo... 1773 [1584]: Sermón X: 130.

94 Ibídem: 123.

${ }^{95}$ Réau, L. 1998: 313. Gisbert, T. 2008: 48. 


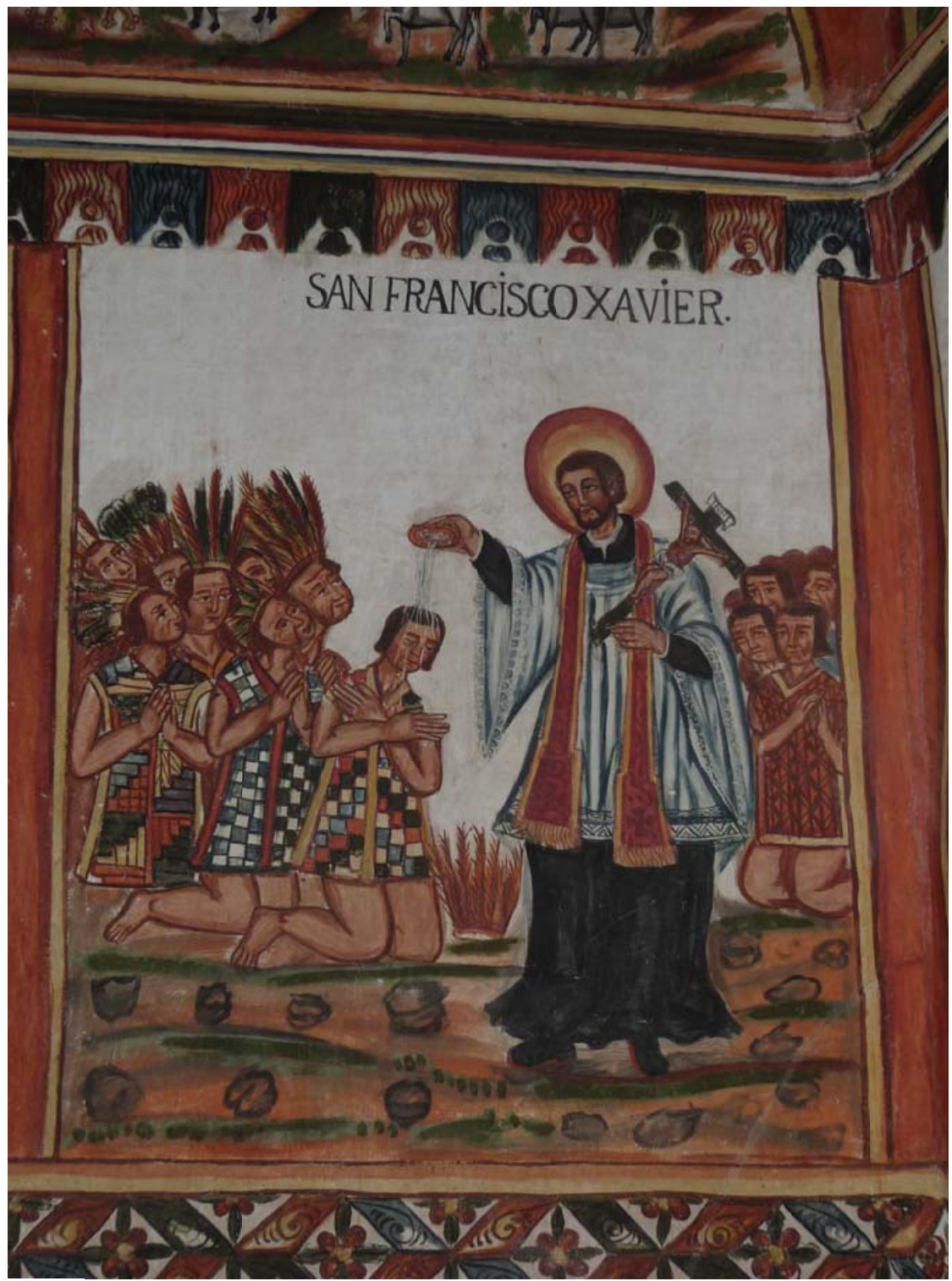

Figura 5. San Francisco Javier bautizando indios principales. Iglesia de Santiago de Curahuara de Carangas. Siglo XVIII.

A continuación, la exposición de la doctrina se detiene a explicar cómo puede alcanzar la salvación el que comete pecados después de haber sido bautizado: "¿Y si son bautizados, y han tornado a pecar, que han de hazer para no ser condenados? Confesar sus culpas al sacerdote, arrepintiéndose de ellas", ${ }^{96}$ repetían de memoria los indios catequizados, siguiendo la fórmula del Catecismo Menor. Al salir de las iglesias de Parinacota y Pachama se pueden ver escenas de sacerdotes impartiendo la penitencia, su observación serviría para recordar la necesidad del sacramento cristiano para limpiar el alma y la inconveniencia de volver a la práctica andina de revelar los pecados, cuya función no era borrar las faltas sino protegerse de las

${ }^{96}$ Catecismo Menor, en Doctrina Christiana... 1584:17r. 
consecuencias que las faltas podían acarrear en esta vida. Se debe recordar que en las culturas andinas existía la costumbre de confesar los pecados ante un ministro denominado ichuri, quien indicaba algunos actos rituales para lograr la purificación. Parece, por tanto, que no fue tan difícil lograr que los indios acudieran al sacramento de la penitencia, dado que estaban acostumbrados a contar sus faltas; lo complicado era, sin embargo, erradicar la antigua práctica de la confesión andina ${ }^{97}$ así lo señala explícitamente el texto del décimo primer sermón: "Vuestros antepasados confesaban sus pecados a los confesores del diablo, a los ichuris, y hoy día algunos hacen tan gran maldad". ${ }^{98}$ Una de las pinturas de Parinacota representa al sacerdote escuchando la confesión de un penitente que expulsa una serpiente y dos sapos, ${ }^{99}$ imagen que recordaría de inmediato las palabras del décimo primero sermón: "Sabed que cuantos pecados dices, tantos demonios y sapos feos vomitas". ${ }^{100}$ La conexión de imágenes y palabras se orienta a forjar la convicción de que sólo con el sacramento de la penitencia el "cristiano que ha caído en pecado mortal es perdonado"; ${ }^{101}$ la repetición memorística de la respuesta del Catecismo Mayor terminaría de cerrar el círculo: "el christiano confiesa todos sus pecados mortales que se acuerda de aver hecho". ${ }^{102}$ En los muros de Pachama, a la izquierda de la puerta, se pintó una ciudad en la que se desarrollan dos escenas: en la primera de ellas unas mujeres disfrutan despreocupadamente de la música que un hombre ejecuta, en la segunda unas religiosas hacen fila para confesarse; se trataría de una forma peculiar de mostrar la vía ancha y cómoda que conduce a la perdición, y el camino estrecho, de expiación, que lleva al cielo. El pecador no debe desesperar, "Dios que es padre misericordioso, y que conoce nuestras flaquezas, y enfermedades, ordenó una medicina, y remedio para todos esos males, y llagas que es la confesión, que por otro nombre se llama Sacramento de penitencia". ${ }^{103}$

97 La persistencia de la confesión andina se explica, al menos en parte, por la diversidad de efectos entre esta práctica y el sacramento de la confesión.

98 Tercero Catecismo... 1773 [1584]: Sermón XI: 136.

${ }^{99}$ Estenssoro, J.C. 2001: 465-471.

100 Tercero Catecismo... 1773 [1584]: Sermón XI: 149.

101 Ibídem: 134.

102 Catecismo Mayor, en Doctrina Christiana... 1584: 50a.

103 Tercero Catecismo... 1773 [1584]: Sermón XI: 134. 


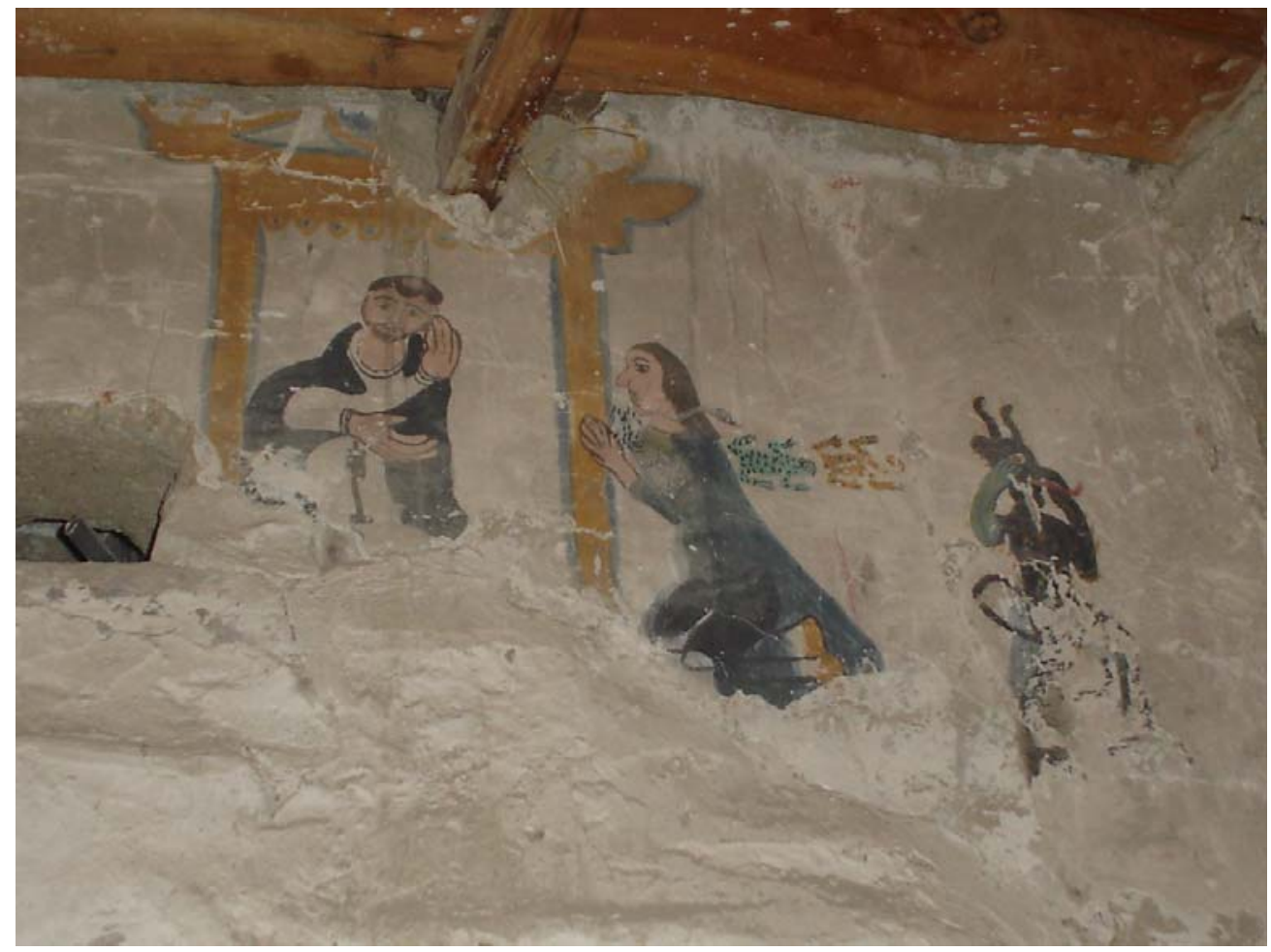

Figura 6. La Confesión. Iglesia de la Natividad de Parinacota. Siglo XVIII.

El Catecismo Mayor recuerda que para obtener la salvación es necesario, además de recibir el sacramento del bautismo y de la penitencia, participar de la Eucaristía; ${ }^{104}$ por ese motivo la Iglesia manda comulgar una vez al año, por Pascua, y en peligro de muerte, como lo recuerda el catecismo. ${ }^{105}$ En la iglesia de Curahuara de Carangas el muro del Evangelio tiene pintado una escena en la que Cristo muestra una Custodia mientras la Virgen y San José se encuentran en actitud de adoración y los santos Padres, San Ignacio de Antioquía, San Justino y San Agustín, escriben sus reflexiones en torno al Sacramento; la pintura intenta mostrar la enormidad del misterio y su centralidad en la vida cristiana. ${ }^{106}$ Es probable que al mirar la pintura, la memoria volviera hacia una de las respuestas con mayor profundidad teológica del catecismo; se trata de aquella que se cuestiona acerca de la finalidad del sacramento: "Para dos cosas, principalmente. La primera, para sacrificio singular, que ofrezcamos al Padre eterno, por nuestros pecados, y necesidades, y esso haze los sacerdotes en la Missa siempre que celebra. La segunda, para mantenimiento de nuestras ánimas, que nos de vida de gracia lo qual haze quando los fieles le resciben dignamente". ${ }^{107}$ En Parinacota, en

104 Ibídem: 165

105 Catecismo Mayor, en Doctrina Christiana... 1584: 49r.

106 Gisbert identifica esta escena como la Trinidad con los doctores: Gisbert, T. 1998: 153. La representación estaría emparentada con los triunfos de la Eucaristía inspirados por la Contrarreforma. Réau, L. 1998: 442-443.

107 Catecismo Mayor, en Doctrina Christiana... 1584: 49a. 
el muro de la epístola, se pintó un cuadro de adoración a la Eucaristía en el que se ve a dos orantes de rodillas frente a una Custodia, ${ }^{108}$ imagen que podría relacionarse con la frase del vigésimo primero sermón: "Quando alzan la hostia, y el caliz estamos de rodillas, y nos herimos en los pechos, adorando a nuestro Señor Jesu Christo, cuyo cuerpo, y sangre preciosa está verdaderamente en aquella hostia, y en aquel cáliz después de consagrados"; ${ }^{109}$ la representación y el texto de la prédica se articularían con la recitación memorística de la fórmula del catecismo: "Está el verdadero cuerpo y sangre de Jesu Christo nuestro Señor, y así adoramos al mismo Dios, que está allí, el mismo que en el cielo, por manera maravillosa". ${ }^{110}$

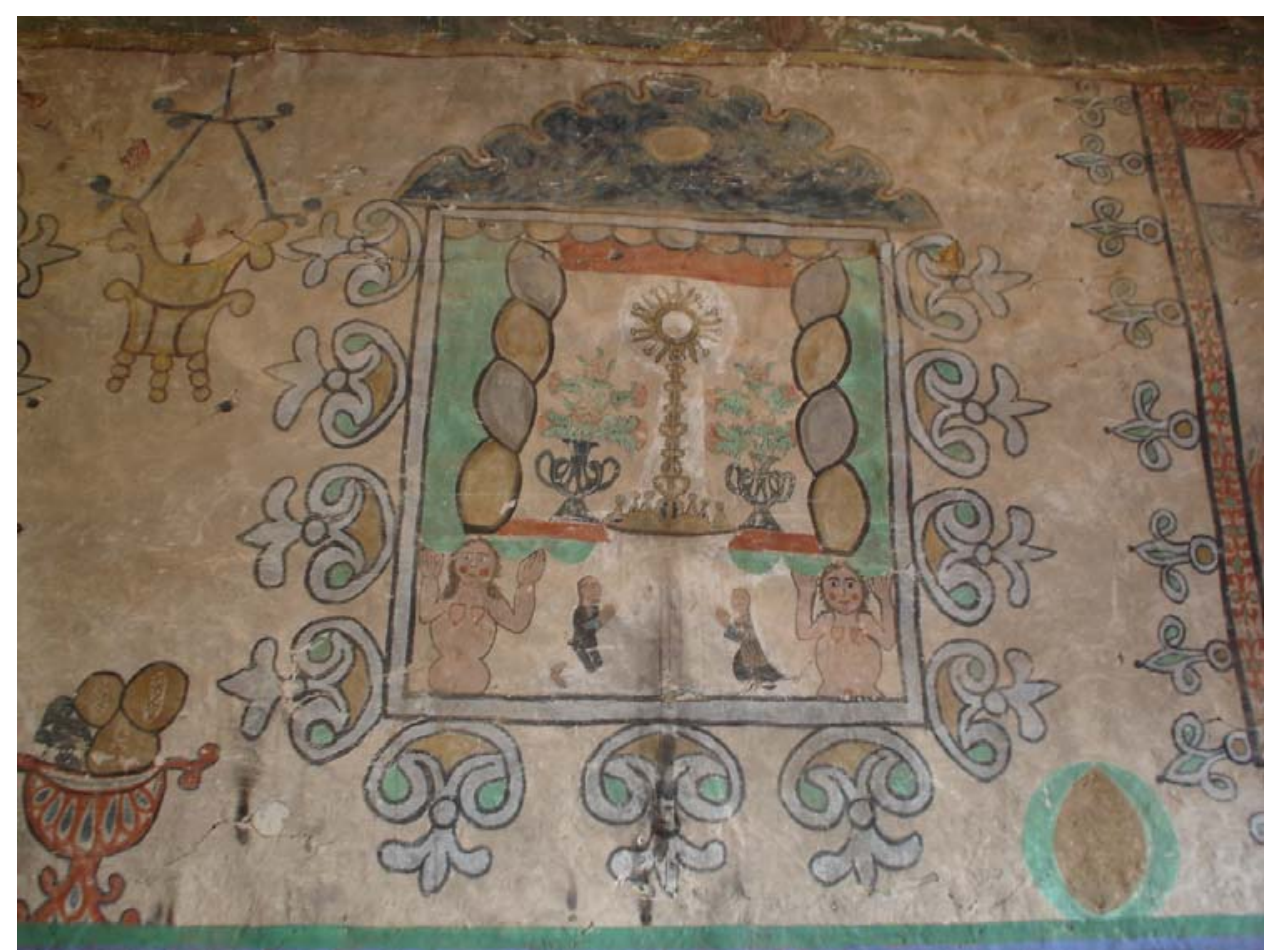

Figura 7. Adoración de la Eucaristía. Iglesia de la Natividad de Parinacota. Siglo XVIII.

\section{PECADOS Y SANTIDAD}

Tal como se indicó, en la dimensión moral de la catequesis también se pueden observar algunos énfasis. La lectura de los textos limenses permite distinguir algunas secciones en que se expone una enseñanza de carácter general, de otras en que es indudable que se hace referencia a circunstancias concretas del ámbito andino; evidenciando de este modo la conciencia de que los indios tienen algunos vicios que les son propios y que sería necesario erradicar. El énfasis está puesto en la descripción de los pecados de idolatría y

\footnotetext{
${ }^{108}$ Corti, P., Guzmán, F. y Pereira, M. 2013: 49.

109 Tercero Catecismo... 1773 [1584]: Sermón XXIX: 450.

110 Catecismo Mayor, en Doctrina Christiana... 1584: 48r.
} 
hechicería, a los cuales el Catecismo Mayor le dedica tres páginas, el Confesionario ocho, el Tercero Catecismo más de treinta; estos antecedentes se pueden comparar con el tratamiento del cuarto mandamiento en los mismo documentos; sólo una página en el Catecismo Mayor, una en el Confesionario y doce en el Tercero Catecismo; diferencia cuantitativa que parece indicar la necesidad de enfatizar la transmisión de algunas normas morales, en desmedro de otras que los indios cumplirían sin grandes dificultades. Otro pecado que tiene un tratamiento especial es el de borrachera, particularmente ilustrativo resulta la decisión del Tercero Catecismo de dedicarle un sermón especial; debe tenerse en cuenta que los aspectos morales se desarrollan en textos que tratan de cada uno de los mandamientos, incluyendo ahí la descripción de pecados de diversa naturaleza, los únicos pecados específicos que presentan un capítulo independiente son la hechicería y la borrachera. ${ }^{111}$ Finalmente, pareciera haber un acento especial en el tratamiento de algunos pecados contra el sexto mandamiento, en particular el amancebamiento y las relaciones entre personas del mismo sexo.

Las pinturas del infierno en Parinacota y Copacabana de Andamarca son bien explícitas en mostrar el pecado de idolatría. En la primera iglesia, un alma condenada es obligada a arrodillarse y adorar a un demonio, representando el culto invertido. En los muros del templo boliviano un indio que sufre los tormentos infernales y el mismísimo Leviatán llevan una piedra horadada amarrada al cuello; es probable que se trate de una waca cuyo culto ofreció una especial resistencia al impulso evangelizador. ${ }^{112} \mathrm{El}$ Catecismo pregunta "¿Quién quebranta el mandamiento de honrar a Dios? El que adora cualquiera criatura, o tiene ídolos, o wacas". ${ }^{113}$ El Tercero Catecismo es aún más explícito en el sermón XVIII: "Por este mandamiento se os manda que no adoréis al sol, ni a la luna, ni al lucero, ni a las cabrillas, ni a las estrellas, ni a la mañana, ni al trueno, o rayo, ni al arco del cielo, ni a los cerros, ni

${ }^{111}$ Es indudable que se concibe una vinculación entre los pecados de idolatría y borrachera, tal como lo señala repetidas veces Guaman Poma de Ayala: "que los dichos indios estando borrachos el más cristiano, aunque sepa leer y escribir trayendo rosario y vestido como español, cuello, parece santo, en la borrachera habla con los demonios y mocha a las uacas ídolos y al sol". Guaman Poma de Ayala, F. 2008 [1615]: Tomo II: 548.

112 No existen referencias documentales de procesos de extirpación de idolatría que hayan tenido como escenario al pueblo de Copacabana de Andamarca, sin embargo, el relato que explica la existencia del santuario podría estar indicando la persistencia de un culto prehispánico. Schauer, P. y Gisbert T. 2010: 69. La palabra waca designa lugares sagrados de diversa naturaleza.

${ }^{113}$ Catecismo Mayor: 58 y Confessionario: 6r, en Doctrina Christiana... 1584. 
montes, ni a las fuentes, ni a los ríos, ni a la mar, ni a las quebradas, ni a los árboles, ni a las piedras, ni a las sepulturas de vuestros antepasados...". ${ }^{114}$

En el Juicio Final de Parinacota se puede observar a un condenado que es obligado a beber sin descanso, transformando así el placer en tormento. El confesionario pregunta: "¿Hazte privado de tu juicio emborrachándote, o sido causa que otros emborrachen, induciéndolos o forzándoles a ello?". ${ }^{115}$ El sermón XXIII, dedicado íntegramente al pecado de embriaguez, amonesta a los que están enviciados con la bebida recordándoles la gravedad de la falta: "el juicio que Dios os dio, con que sois hombres y no caballo, no le podéis quitar, ni privaros de él emborrachándoos, porque es matar vuestra ánima". ${ }^{116}$

En el infierno de Curahuara de Carangas se identifican los pecados de la lascivia y la lujuria, en Parinacota, por su parte, se puede ver a un condenado que es acariciado por un repugnante demonio. El Catecismo Mayor recuerda que quebranta el sexto mandamiento todo "el que comete fealdad con mujer ajena o con soltera y mucho más si es con otro hombre... tales maldades las castiga Dios con fuego eterno en la otra vida, y muchas veces en esta presente, con grandes males del cuerpo, y alma". ${ }^{117}$ El Confesionario recoge el repertorio de pecados para ayudar al penitente en su examen de conciencia: “ ¿Has tenido cuenta con otras mujeres solteras o casadas? ¿Antes de casarte cuánto tiempo estuviste con tu mujer? ¿Has usado de pecado nefando con alguna persona? ¿Has usado de bestialidad con algún animal?". ${ }^{118}$

114 Tercero Catecismo... 1773 [1584]: 232-233. Las referencias a la idolatría son abundantes en las crónicas, se puede citar la referencia de Arriaga: "A cerros altos y montes y algunas piedras muy grandes también adoran y mochan, y les llaman con nombres particulares, y tienen sobre ellos mil fábulas de conversaciones y metamorfosis y que fueron antes hombres que se convirtieron en aquellas piedras", Arriaga, Joseph de. 1999 [1621]. La extirpación de la idolatría en el Piru: 28 Cuzco: Centro de Estudios Regionales Andinos "Bartolomé de las Casas". Una observación semejante realiza Acosta: "Mas en los indios, especialmente en los del Piru, es cosa que saca de juicio la rotura y perdición que hubo en esto; porque adoran los ríos, las fuentes, las quebradas, las peñas o piedras grandes, los cerros, las cumbres de los montes que ellos llaman Apachitas, y lo tienen por cosa de gran devoción; finalmente, cualquier cosa de la naturaleza que les parezca notable y diferente de las demás, la adoran como reconociendo allí alguna particular deidad", Acosta de, J. 1979 [1590]. Historia Natural y Moral de las Indias: 224 México: Fondo de Cultura Económica.

115 Confessionario, en Doctrina Christiana... 1584: 10.

116 Tercero Catecismo... 1773 [1584]: 314.

117 Catecismo Mayor, en Doctrina Christiana... 1584: 62 a y 62r.

118 Confessionario, en Ibídem: $11 \mathrm{a}-12 \mathrm{r}$. 
La conciencia de las faltas morales que los cuestionarios de confesión provocaban no debían generar la desesperación en el fiel, sino el arrepentimiento y el deseo de recuperar la gracia y amistad con Dios, tal como lo afirma el proemio del confesionario limense: "no basta examinar bien al penitente y entender enteramente sus pecados, sino también importa y es lo más necesario induzirle y moverle a verdadero arrepentimiento y enmienda de sus culpas". ${ }^{119}$ La redención obrada por Cristo se aplica al hombre arrepentido por medio del sacramento de la penitencia. El pecador contrito puede volver al redil, aún más, debe alcanzar la santidad.

La idea de que la Iglesia se funda en la identificación de los santos con la pasión de Cristo parece estar presente en los programas iconográficos de las iglesias en estudio. Junto a la fuerza de alguna devoción privada o a la necesidad de contar con intercesores, los santos pintados en los muros de Parinacota, Pachama, Curahuara de Carangas y Copacabana de Andamarca, parecen haber sido elegidos para mostrar la relevancia de la vida penitente y el valor del martirio. El VIII Sermón destaca la vida de los mártires diciendo que "se dejaron apedrear y quemar y hacer pedazos por no negar a Jesucristo y de estos hubo millares y millares"; luego ensalza la vida de penitencia: "Hubo otros que se fueron a los desiertos a hacer penitencia y vida áspera por amor de Dios". ${ }^{120}$ Los apóstoles, san Sebastián, san Antonio y san Jerónimo, entre otros, son ejemplos de lo anterior.

${ }^{119}$ Confessionario (proemio), en Doctrina Christiana... 1584: 3r.

120 Tercero Catecismo... 1773 [1584]: 95. 


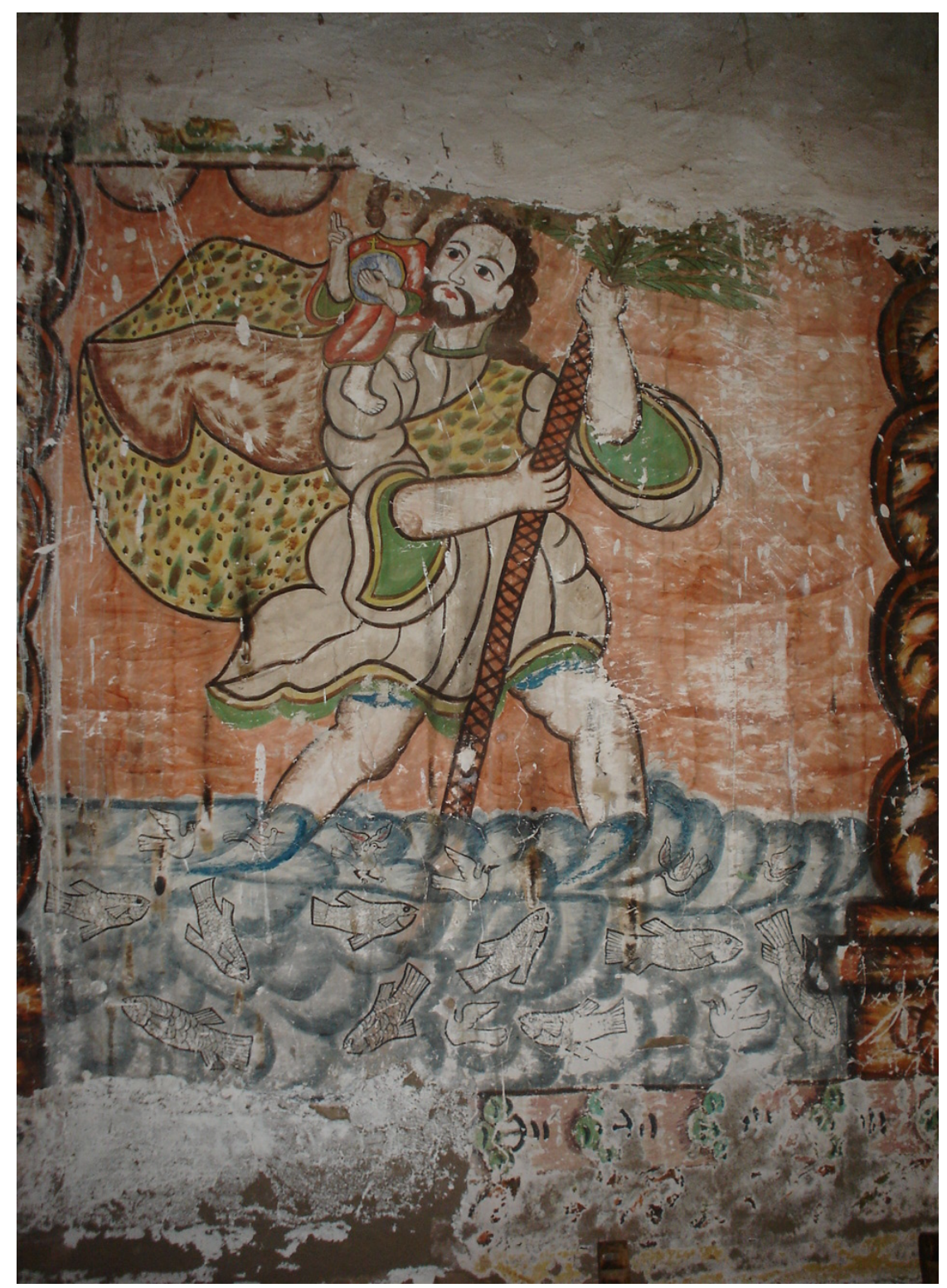

Figura 8. San Cristobal. Iglesia de San Andrés de Pachama. Siglo XVIII.

De especial relevancia resulta la relación entre la contrición de los pecados y la penitencia que se puede encontrar en el relato de la vida de la mayoría de los santos. Especialmente ilustrativas resultan las palabras del IX Sermón respecto de María Magdalena: "Sabed hermanos que había una mujer gran pecadora que se llamaba María Magdalena, la cual oyendo al Señor predicar, movida de su palabra, vino a buscarle a casa de un fariseo adonde comía: y llegando por detrás con mucho dolor y vergüenza derramó tantas lágrimas que con ellas lavó los pies de Jesucristo y luego los limpiaba con sus cabellos y los besaba con su boca". ${ }^{121}$

121 Ibídem: 115. 


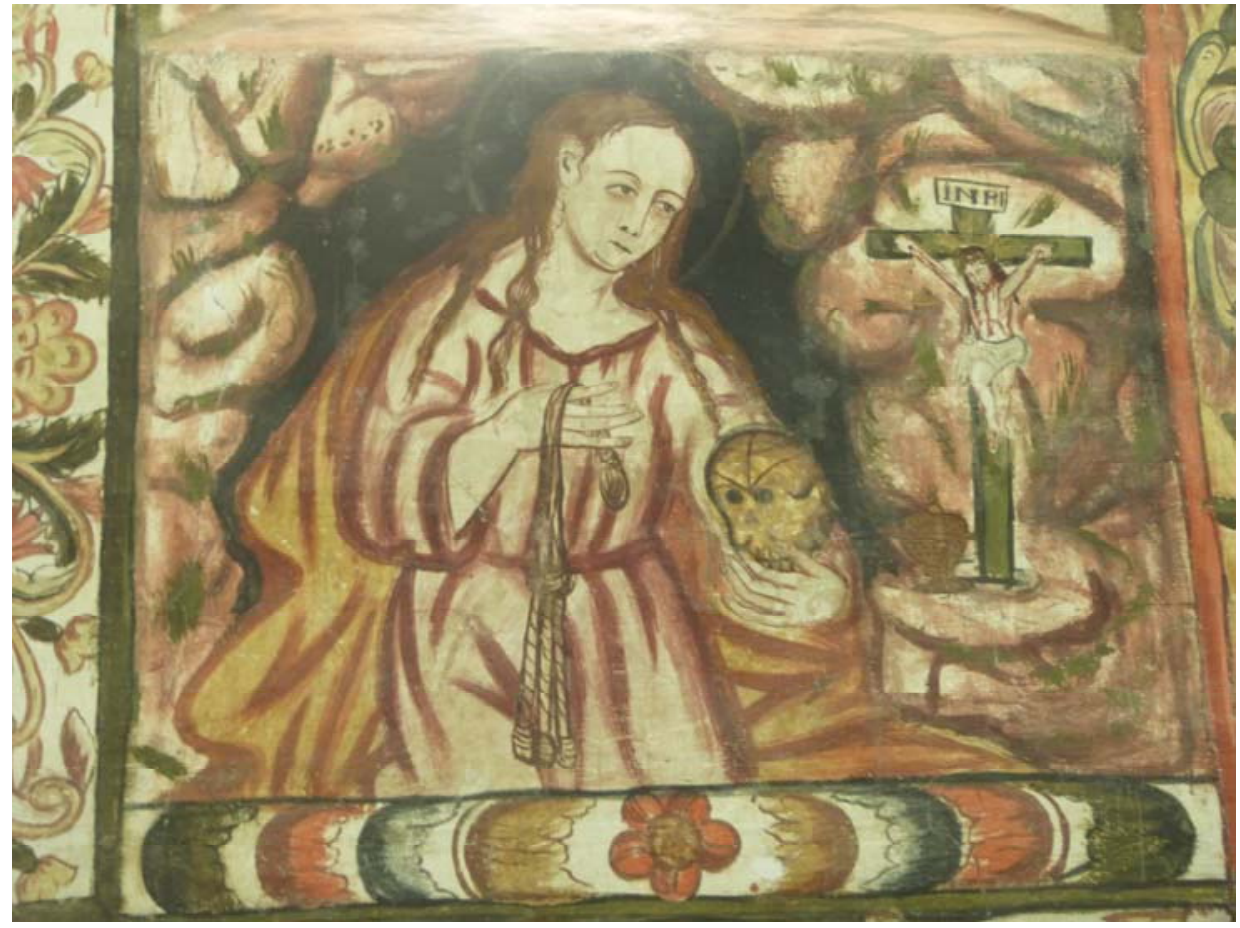

Figura 9. Santa María Magdalena. Iglesia de Santiago de Curahuara de Carangas. Siglo XVIII.

Las imágenes de estos santos y las palabras de los sermones se conectarían para recordarles a los habitantes de estos pueblos que la vida cristiana no consistía solamente en evitar el pecado; se requería el sincero arrepentimiento de las faltas cometidas y la voluntad de identificarse con el sacrificio redentor de la Cruz como lo habían hecho: san Simeón Estilita, san Isidro Labrador o san Cristóbal, todos presentes en los muros de las iglesias estudiadas.

\section{EL CLERO Y LA CRISTIANIZACIÓN DE LA MEMORIA}

La identificación de diversos puntos de contacto entre las pinturas murales, el catecismo y los sermones permite vislumbrar el papel que jugaron las imágenes en el proceso de catequesis en la Ruta de la Plata, como en muchos otros sitios en el continente. Sin embargo, saber que en el catecismo se habla del Juicio Final y que las postrimerías están pintadas en los muros de las iglesias no es suficiente para comprender la forma cómo estos elementos se almacenan, enlazan y activan en la memoria de un aymara de Parinacota en el siglo XVIII. Enfrentar la comprensión de este fenómeno requiere, en primer lugar, conocer la manera en que concebían los sacerdotes el proceso de memorizar la doctrina, identificando los procedimientos de articulación de imágenes y palabras que ellos utilizaban y en los que harían ejercitarse a los indios.

La preparación de los sacerdotes, sobre todo después del Concilio de Trento, consideraba el estudio de los escritos de San Agustín y Santo Tomás de Aquino como uno de los fundamentos de su formación, como 
lo establece la real cédula del 14 de agosto de $1768 ;{ }^{122}$ de este modo, los procedimientos de la escolástica se proyectaban al mundo moderno. ${ }^{123}$ Uno de los elementos de esta tradición medieval que se transmite a través de los estudios eclesiásticos durante los siglos XVII y XVIII es precisamente lo relativo al ars memorativa. El estudio de comentaristas del Aquinate fue el medio principal, aunque no exclusivo, a través del cual el clero católico tuvo contacto con el arte de la memoria. ${ }^{124}$ Siguiendo a Frances Yates se puede afirmar que el doctor angélico elabora su discurso acerca de la memoria a partir del Ad Herennium, texto atribuido erróneamente a Cicerón. ${ }^{125}$ De esta fuente clásica habría extraído las reglas de lugares e imágenes que instruyen al iniciado respecto de la necesidad de recordar a partir de imágenes impactantes distribuidas en los distintos recintos de un edificio previamente aprendido. ${ }^{126}$ Las viejas reglas retóricas son retomadas por el dominico, recomendando que los diversos tópicos de un discurso se asocien a una forma sensible de características inusitadas que se deben ubicar ordenadamente en un espacio arquitectónico. De este modo la memoria recorre el edificio encontrándose en cada habitación con una imagen que se vinculará con una de las ideas de algún discurso.

Con todo, como se encarga de precisar Yates, la concepción de Santo Tomás, como ocurre con otros pensadores medievales, difiere del arte de la memoria clásico en varios aspectos. La primera diferencia es que la memoria es una parte de la prudencia, entendida como virtud eminente para el recto actuar del cristiano, por tanto, su fin no es sólo la de ordenar un discurso o sermón, sino más bien la de ayudar a discernir lo que es bueno o malo, impulsando a la persona a buscar lo primero y rechazar lo último. Un segundo rasgo es que, siguiendo en parte a Alberto Magno, considera que los lugares elegidos deben ser solemnes, como una iglesia, sin demostrar especial preocupación por las complejas reglas que guiaban la elección de lugares en el sistema clásico; para el santo se trata más bien de distribuir ordenadamente las imágenes en un lugar recogido, apropiado para la devoción. Finalmente señala la necesidad de ser solícito (sollicitudo) en la ejercitación de la memoria, alterando una recomendación de los antiguos tratados según los cuales

122 Vergara, J. 2004. Historia y pedagogía del seminario conciliar en Hispanoamérica, 1536-1800: 176 Madrid: Editorial Dykinson.

123 Ibídem: 165-182.

${ }^{124}$ Se debe tener en cuenta que la lectura directa de las obras de Santo Tomás debió ser una excepción entre los seminaristas de los siglos XVII y XVIII. La mayoría de los catedráticos conocía la Summa, pero los alumnos estudiaban la filosofía a través de los comentarios de Antoine Gaudin y la teología en los textos de Pedro Godoy, Jean Baptiste Gonet, Guillaume Contenson o Domingo de Soto. Ibídem: 169 y 178.

125 Yates F. 2005. El Arte de la Memoria: 18 Madrid: Ediciones Siruela.

126 Ibídem: 22. 
las imágenes se debían destacar solitariamente (sollitudo); Francis Yates observa que "la solicitud del Aquínate implica penetrar con afecto en las cosas que se han de recordar, introduciendo, pues una atmósfera de devoción que estaba enteramente ausente en las reglas de la memoria clásica". ${ }^{127}$ De hecho, el Aquinate propone el ejercicio habitual (habitus) en la meditación de imágenes vinculadas a la memoria mediante un afecto (affectus); dicho afecto es el que adhiere las imágenes sensibles al alma permitiéndole recordar fácilmente, impidiendo así que se deslice de la misma el recuerdo de las cosas espirituales. ${ }^{128}$ Como vemos, la acción del prudente cristiano requiere de la memoria para recordar lo debido y actuar en conformidad, en vistas a la Salvación final.

La práctica de vincular imágenes y lugares con miras a asistir a la virtud de la prudencia fue un patrimonio común no sólo de frailes y sacerdotes que estudiaban el pensamiento de Santo Tomás, sino que se trataba de una noción compartida a la que se podía acceder de diversas maneras. Efectivamente, la lectura de Santo Tomás o sus comentaristas era una de las vías posibles para acceder al ars memorativa. Durante los siglos XVI y XVII se publicaron numerosos tratados de mnemónica en España, tanto en latín como en castellano, destacando entre otras el Rhetoricae Exercitationes, publicado en 1569 por Alfonso de Torres, Rethorica Eclesiástica de Fray Luis de Granada, publicada en 1576 o el De Arte Rethorica, publicada en 1611 por el jesuita Francisco Bermúdez. ${ }^{129}$ Además de los tratados teóricos, muchas obras de otra naturaleza, como los Ejercicios Espirituales de San Ignacio y Las Moradas de Santa Teresa, ${ }^{130}$ contenían la lógica de los lugares y las imágenes. Otro testimonio de la difusión del arte de la memoria lo constituyen las referencias a personas con memorias prodigiosas, así como la extrañeza que producían los oradores o predicadores que se apoyaban en un papel. ${ }^{131}$

A pesar del aparente predominio del ars memorativa en su vertiente escolástica, es posible que algunos sacerdotes activos en América hayan tomado contacto con otras formas de mnemónica, divergentes de los planteamientos de Tomás de Aquino. Sobre todo debe hacerse referencia al Ars Magna del franciscano Raimundo LLul, publicada entre 1305 y $1308 .{ }^{132}$ El pensamiento del fraile presenta variantes significativas, especialmente por basarse en diagramas y no en

127 Ibídem: 97.

${ }^{128}$ Aquino, Santo Tomás de. Summa Theologica: II, II, q. 49, art. 1.

129 Egido, A. 1986. "El arte de la memoria y El Criticón", en: 1986. Gracián y su época: 32 Zaragoza: Institución Fernando el Católico.

130 Gerli, M. 1984. "El castillo interior y el arte de la memoria". Bulletin Hispanique T. 86: № 1-2: 154-163.

131 Ibídem: 160-161.

132 Yates, F. 2005: 198-199. 
imágenes figurativas, y por reemplazar los lugares arquitectónicos por esquemas arbóreos. ${ }^{133}$ Es posible que algunos religiosos de la orden seráfica se nutrieran y pusieran en práctica las ideas de Llul. Sin embargo, el franciscano Diego de Valadés en su Rhetorica Christiana, tan cercana al mundo de esquemas del Ars Magna, parece seguir más a Quintiliano y a Santo Tomas que al fraile catalán a la hora de establecer una práctica de memoria. ${ }^{134}$ Otra tradición de pensamiento en torno a la memoria, y su valor, también alimentó el patrimonio intelectual franciscano; se trata de una tradición que corre desde San Agustín, pasando por el mundo cisterciense, para llegar a consolidarse entre los franciscanos de los siglos XIII y XIV, y en su práctica extendida de los sermones bajomedievales, de los cuales serán también herederos los predicadores en los siglos XV y XVI. En ella, y siguiendo a San Agustín, ${ }^{135}$ la memoria es considerada no como dependiendo de la imaginatio, es decir, una facultad del orden sensible, sino como una potencia o virtud del alma, al lado de la intelligentia y de la voluntas; estas tres potencias se encuentran afectadas por el pecado original, y es tarea del hombre en su recta vida cristiana, el limpiarlas de los efectos del pecado para que se ordenen a Dios. En el siglo XII, san Bernardo de Claraval, hablará de la necesidad de cultivar y formar una "memoria munda", ${ }^{136}$ una memoria limpia, en la que las buenas imágenes limpien el recuerdo del pecado y permitan la conversión (conversio); más tarde, un franciscano como David de Augsburgo (1200-1272), en la misma línea de pensamiento, recordará a los novicios y predicadores que la memoria no limpia (inmunda), está sometida a una suerte de vagabundeo imaginativo, una verdadera lujuria de imágenes ${ }^{137}$ que impiden al hombre un recto pensar, de allí la necesidad de "fijar" la memoria a través de la meditación en buenas imágenes que le permitan cultivar la virtud. ${ }^{138}$ Para

133 Ibídem: 199-210.

134 Taylor, R. 1987. El arte de la memoria en el nuevo mundo: 49-51 El Escorial: Editorial Swan.

135 San Agustín. De Trinitate, libro X, caps. 10-13; San Agustín, Confessiones: libro X.

136 San Bernardo, De conversione, citado en Carruthers, M. 2000. The Craft of Thought: Meditation, Rhetoric and the Making of Images, 400-1200: 94 Cambridge: Cambridge University Press. Esta limpieza de la memoria no significa borrar todo recuerdo del pecado (oblitterare), sino la pérdida de su efecto en el corazón humano a través de la compunción (compunctio cordis) que, de esta forma, se vuelve misericorde. Una munda memoria, en la que se disponen buenas imágenes, lleva al mundo corde, que permite disponer el corazón (memoria) a la visión de las cosas divinas.

${ }^{137}$ Esta idea ya aparece en Juan Casiano, quien habla de la curiositas o fornicatio como el vagabundeo de la mente deslizada en distintas ideas sin orden ni objetivo, de allí que el alma deba procurar su estabilidad mediante la vigilia, la meditación y la oración. Carruthers, M. 2000: 83.

138 Los escritos de David de Augsburgo (De institutione novitiorum, De profectu religiosum, entre otros), son poco conocidos, pero de importante 
ello, es necesario disponer en ella la imagen y el recuerdo de las buenas cosas, sobre las cuales la memoria pueda dirigir su atención y estabilizarse en orden a permitir la meditación y la contemplación. En este sentido, y como también lo afirma San Buenaventura, dos deben ser los ejes de toda meditación: la Pasión de Cristo, que mueve a compunción y ejemplo, y el Juicio Final, que permite la conversio morum. ${ }^{139}$

Tampoco debe descartarse la posibilidad de que las tendencias neoplatónicas y herméticas que modifican el arte de la memoria durante el Renacimiento tuviesen algún impacto entre sacerdotes activos en América. No obstante, se puede afirmar que todos los sacerdotes habían estudiado, aunque fuese de manera mediada, al teólogo dominico y que sólo algunos habrían tenido acceso a otras formas de mnemónica. Las manifestaciones de la sobrevivencia del arte de la memoria en el clero activo en América son abundantes, como lo explica Mujica Pinilla; ${ }^{140}$ algunos sacerdotes, como Mateo Ricci en China, ${ }^{141}$ entenderían todas las implicancias de la cristianización de la memoria, otros, quizá la mayoría, no serían conscientes de las consecuencias culturales de lo que estaban realizando.

De modo que, sin quizá proponérselo, la mayoría de los sacerdotes inducirían a los indios a vincular las fórmulas del catecismo con imágenes, y estas con lugares dentro de un edificio, esperando que, posteriormente, el catequizado pudiera recorrer el edificio de su memoria encontrándose con imágenes impactantes a través de las cuales podría recordar los efectos de cada sacramento o los momentos de la Pasión de Cristo. Dicho de una manera más concreta, los edificios de la memoria propuestos serían las iglesias de Curahuara de Carangas, Copacabana de Andamarca, Pachama y Parinacota, y las imágenes impactantes serían las pinturas en sus muros. Frailes y curas esperarían que los indios pudiesen repasar de esta manera lo aprendido; no se trata, por tanto, sólo de pinturas que están en la iglesia para ser vistas en algunas ocasiones, se trata de imágenes que se custodian en la memoria y que

incidencia. Vid. para ello la excelente obra de Rivers, K. 2010. Preaching the Memory of Virtue and Vice. Memory, Images, and Preaching in the Late Middle Ages: 125-145 Brepols: Turnhout, en donde aborda el problema de la memoria y la meditación en la tradición franciscana medieval.

139 Ibídem: 129-140.

140 Mujica Pinilla, R. 2002. "El arte y los sermones", en El Barroco Peruano: Lima: Banco de Crédito. Mujica Pinilla, R. 2006. " "Reading without book" -On sermons, figurative art, and visual culture", en Stratton-Pruitt, S. The Virgin, Saints, and Angels, South American paintings 1600-1825 from the Thoma collection: Stanford : Skira editore.

141 Jonathan, S. 2002. El palacio de la memoria de Matteo Ricci. Un jesuita en la China del siglo XVI: Barcelona: Tusquets Editores. 
se hacen presentes una y otra vez y en toda circunstancia: en medio del trabajo, antes de dormirse o al terminar de comer. Un habitante de Parinacota podría recorrer de memoria la pequeña iglesia del pueblo encontrándose con las pinturas murales en sus ubicaciones específicas, al hacerlo podría recitar el catecismo completo desde el "da gloria eterna a los buenos que le sirven, y pena eterna a los malos que lo ofenden"142 ante la contemplación de las escenas del Juicio Final, avanzando hasta el "Está el verdadero cuerpo y sangre de Jesu Christo nuestro Señor"143 frente a la imagen de la adoración de la Eucaristía con su enorme custodia y sus devotos orantes.

En este ejercicio de reconstruir las prácticas de memoria que los sacerdotes inculcarían a los indios en el contexto de la catequesis, se debe recordar que en la concepción medieval la memoria queda vinculada con la virtud de la prudencia. ${ }^{144}$ Para distinguir entre el bien y el mal se requiere recordar oportunamente criterios y nociones que colaboren a tomar una decisión en sintonía con la moral cristiana. A la hora de discernir se debe recorrer ágilmente el edificio de la memoria para revisar los lugares donde se guardan las imágenes impactantes que contienen los principios, ejemplos o anti ejemplos necesarios para tomar una decisión. De modo que, el efecto esperado no es exactamente que los habitantes de Pachama o Copacabana de Andamarca recorran el edificio de la memoria para discurrir teóricamente en torno a los diversos aspectos de la doctrina cristiana, sino que se trata, ante todo, de aportarle un repertorio de lugares e imágenes que les permitan actuar rectamente. El pastor que cuida sus llamas en el bofedal debe decidir si se acerca al sacerdote para contarle sus pecados; mientras lo hace recorre mentalmente la iglesia de Parinacota y se encuentra, en el muro del coro, con la pintura de un sacerdote que escucha la confesión de un penitente de cuya boca salen sapos y culebras, la imagen lo lleva a recordar las palabras del sermón: "sabed que cuantos pecados dices, tantos demonios y zapos feos vomitas", 145 incoándose el deseo de librarse de esas raposas interiores. ${ }^{146}$ La mujer que prepara una watia no está segura de la necesidad de bautizar a su hijo, su inquietud le lleva a recorrer de memoria el templo de Curahuara de Carangas, penetrar en el Baptisterio y observar la pintura de San Francisco Javier bautizando a un grupo de indios principales, la imagen le permite recordar la fórmula que estudiara en el catecismo acerca de este sacramento: "nadie puede ser salvo sin recibir el sancto baptismo". 147 El hombre que no puede dormir pensando en la estrategia para intimar con la que no es su mujer, no

\footnotetext{
142 Summa de la Fe, en Doctrina Christiana... 1584.

143 Catecismo Mayor, en Ibídem: 48r.

144 Yates, F. 2005: 87.

145 Tercero Catecismo... 1773 [1584]: Sermón XII: 149.

${ }^{146}$ Estenssoro, J. C. 2001: 465-471.

147 Catecismo Mayor, en Doctrina Christiana... 1584: 47r.
} 
podrá evitar ver en su memoria cómo se abren las puertas de la iglesia de Curahuara de Carangas y frente a él -en el muro de la epístola- se le aparece la imagen del Juicio Final con su agobiante infierno en el que una pareja de amantes es torturada por espantables demonios, visión que quizá le haría recordar las expresiones del sermón XXIV: "Dios dice que irá al infierno para siempre sin fin el que toma la muger agena". ${ }^{148}$

Esta presencia permanente de los lugares, las imágenes y las palabras accionadas por la virtud de la prudencia con el objeto de discernir entre lo correcto y lo incorrecto, sería lo que los sacerdotes concebían que debía ocurrir y en esa dirección apuntaban sus esfuerzos. Sin embargo, no es posible suponer que la articulación de los factores ocurriera siempre así. La población aymara se debió ejercitar en el arte de la memoria de acuerdo a la lógica tomista que conocía la mayoría de los sacerdotes, sin embargo, no se puede pensar que recibieran un entrenamiento sistemático como al que se sometía un retórico de la antigüedad $\mathrm{o}$ un monje medieval. La libre asociación de imágenes y palabras tendría, por tanto, un campo para producir efectos difíciles de perseguir desde el punto de vista histórico. Lo que sí se puede indagar son las formas de memoria andina y su posible interferencia con las prácticas que los sacerdotes intentaban introducir. Debe tenerse en cuenta que en muchas localidades la transmisión de la doctrina estaba en manos de indígenas -el III Concilio Limense indicaba que en ausencia de sacerdote el catecismo fuese enseñado por "algún mancebo bien instruido" 149 - cuya formación en el arte de la memoria sería escasa.

\section{MEMORIA ANDINA Y CATEQUESIS}

Identificar las formas de memoria andina, intentando reconstruir el modo en que estas prácticas pudieron dificultar o facilitar la asimilación de las nuevas formas de almacenar imágenes y palabras, es indispensable para aproximarse a una visión más compleja del fenómeno en estudio. En un artículo de Bouysse-Cassagne se proponen algunos de los rasgos que caracterizarían la memoria de los indios en las regiones andinas. ${ }^{150}$ Luego de identificar las circunstancias que dificultan la investigación acerca de este ámbito de la cultura, la autora expone tres vías de aproximación al problema: las palabras, los muertos y la escritura. Las conclusiones tienen una especial relevancia para comprender las circunstancias en las que debió desenvolverse el proceso de evangelización y catequesis entre los siglos XVI y XVIII. En

148 Tercero Catecismo... 1773 [1584]: Sermón XXIV: 338.

149 Tercer Concilio Limense... 1982: 171.

150 Bouysse-Cassagne, T. 2000. "Les mots, les morts et l'ecriture: artes de la mémoire et évangelisation dans les Andes". Cahiers des Amériques Latines $33: 57-80$. 
primer lugar, se destaca la admiración que producía la capacidad de algunos indios para reproducir grandes relatos y la relevancia que tenían las canciones rituales como contenedoras de la memoria colectiva. En segundo término, se reflexiona en torno al papel de los cuerpos de los antepasados como depositarios de la historia de la comunidad, narraciones a las que se accedía trasladándose hasta el lugar donde se encontraba la waca que era interpelada por un mediador. Finalmente, se analiza la función que cumplieron los textiles como contenedores de memoria, reflexionando en torno a su carácter de escritura de lana.

La notable capacidad que algunos indios demostraban para retener y repetir extensos relatos, habitual en culturas carentes de escritura, pudo ser un rasgo que facilitara significativamente el aprendizaje del catecismo. Bernabé Cobos se refiere específicamente a la admiración que producía la seguridad y agilidad que los indios demostraban al recordar todo lo referente a su religión, "dado que no las tenían por escrito para sabellas y guardallas, suplían esta falta con aprenderlas y guardarlas por tradición tan exactamente, que parece las tenían esculpidas en los huesos". ${ }^{151}$ Sin embargo, un primer problema sería que esas habilidades memorísticas extraordinarias no eran patrimonio de todos, las extensas historias eran aprendidas por algún miembro de la comunidad que había sido entrenado para ese fin, ${ }^{152}$ como nos los recuerda Cobo: "para sólo este fin tenían los Incas puestos en la ciudad del Cuzco más de mil hombres que no entendían en otra cosa más que en la conservación de esta memoria". ${ }^{153}$ De modo que, para el común de la población podría haber sido dificultoso aprender textos extensos palabra por palabra; lo anterior parece quedar refrendado por el hecho de que el catecismo redactado en Lima cuente con dos versiones, el mayor para los que son más capaces, y el breve para rudos y ocupados, división que se justifica afirmando que "no son todos de una misma habilidad y memoria". ${ }^{154}$

Una diferencia importante entre las prácticas occidentales y andinas de memoria surgiría de la costumbre indígena de repetir las historias en un contexto ritual y por medio de canciones, ${ }^{155}$ tal como lo describe Joseph de Acosta, "Tañen diversos instrumentos para estas danzas: unas como flautillas o cañutillos; otros, como a tambores; otros, como caracoles; lo más ordinario es en vez cantar todos, yendo uno o dos diciendo sus poesías y acudiendo los demás a responder con el pie de la copla. Algunos de estos romances eran muy artificiosos y contenían

${ }^{151}$ Cobo, B. 1989. Historia del Nuevo Mundo: 306 Sevilla: Imprenta de E. Rasco.

152 Bouysse-Cassagne, T. $2000: 60$.

153 Cobo, B. 1989: 306.

154 Epístola del Concilio, en Doctrina Christiana... 1584.

155 Bouysse-Cassagne, T. 2000 : 60-63. 
historia; otros eran llenos de superstición; otros eran puros disparates". 156 Algo semejante señala Cobo al describir las exequias fúnebres de los indios, "en los cantares repetían y traían a la memoria las hazañas y cosas más memorables que sabían dél, contaban los lugares donde había vivido, las buenas obras que les había hecho, con cuanto podía ser motivo de compasión y llanto". ${ }^{157}$ Se trata de una divergencia importante, la doctrina cristiana no se canta ni se enseña en un contexto litúrgico, al menos regularmente. No obstante, el acto de repetir las repuestas del catecismo con la cadencia característica, ${ }^{158}$ tal como se hacía con las letanías y otras oraciones, aportaría un posible punto de contacto con la memorización de las canciones con historias que se entonaban en contextos rituales andinos. Por otra parte, si bien el estudio de la doctrina cristiana no se produce en un contexto litúrgico, el catecismo señala que el aprendizaje se ha de realizar dentro de la iglesia, ${ }^{159}$ en un espacio sagrado que al menos otorgaba al estudio un ambiente devocional. Los sermones, por su parte, se escuchan dentro de la iglesia e insertos en la celebración de la Misa, por tanto en un contexto ritual que reforzaría su asimilación, ${ }^{160}$ sin embargo, no son textos recitados por la comunidad, solo una persona conoce la historia -el sacerdote- a los demás les compete esforzarse por entender y retener.

Las reglas de lugares que caracterizan al arte de la memoria tendrían un lejano paralelo en las wacas, a las que había que trasladarse o dirigirse para recuperar la historia común. ${ }^{161}$ La práctica de recorrer el edificio de la memoria que los sacerdotes intentarían inculcar a los indios se entronca lejanamente con las visitas a las wacas; la idea de que los recuerdos se guardan en lugares parece estar presente en ambas tradiciones, pero de maneras muy diversas. Las diferencias son evidentes y debieron provocar interferencias significativas. En el modo occidental se recorre un edificio con la imaginación; en la manera andina, por el contrario, se recorre el medio geográfico con los pies o al menos con la vista; tal como lo señala Joseph de Acosta al describir las fiestas que se hacen a las wacas y a los malquis, ${ }^{162}$ el ritual implicaba trasladarse al lugar donde se encontraba el objeto venerado, el hechicero

156 Acosta, J. de. 1979 [1590]: capítulo XXVIII: 241.

157 Cobo, B. 1989: 40.

158 "Lo exerciten recitándolo" dice el catecismo, expresando la necesidad de repetirlo en voz alta con una cierta musicalidad. Epístola del Concilio, en Doctrina Christiana... 1584.

159 Ídem.

160 Surge en este punto la necesidad de analizar la dimensión peformática de la liturgia católica, aspecto que por su complejidad no puede ser desarrollado en el presente trabajo.

161 Bouysse-Cassagne, T. $2000: 63-68$.

162 La palabra malqui designa a los restos de los antepasados. 
"va con sus ayudantes o sacristanes a la Huaca". ${ }^{163}$ No se trata de diferencias irrelevantes, los sacerdotes se toparían con la dificultad de intentar introducir un hábito -el de memorizar espacios arquitectónicosdesconocido y carente de significado para personas que no conocen más que pequeñas edificaciones de volúmenes muy sencillos. ${ }^{164}$ La sintonía entre el arte de la memoria y las prácticas andinas tal vez se restablecería en el acto de impartir la catequesis dentro del templo "exerciten recitándolo a sus tiempos los muchachos y los mayores quando se junten en la Iglesia", ${ }^{165}$ espacio que se podría recorrer con los pies o con la mirada en la búsqueda de las imágenes vinculadas con las preguntas y respuestas que se intentaba memorizar. El hecho de que la catequesis se realizara en la iglesia posee otra implicancia, pues, la doctrina cristiana se aprendería en la presencia de las reliquias de los santos conservados en el altar; es difícil saber hasta qué punto estos restos óseos oficiarían en la mentalidad andina como malquis de los antepasados cristianos y depositarios de las enseñanzas de Cristo; lo cierto es que les atribuyeron poderes extraordinarios ${ }^{166} y$, en muchas iglesias sin reserva eucarística, se constituían en el bien más sagrado del templo.

Otro depósito de memoria en el mundo andino son los textiles; sus formas y colores guardan información que, al menos parcialmente, ha sido decodificada por investigadores como Murra, Flores Ochoa y Marcia y Robert Ascher, ${ }^{167}$ entre otros. Sin embargo, la escritura textil contenida en los khipus, en el vestuario y en otro tipo de piezas, presenta el escollo, aparentemente insalvable, de la imposibilidad de interpretar con exactitud su significado, como lo expresa Urton respecto de los khipus "hoy estamos tan lejos de saber cómo identificar e interpretar un khipu, como lo estuvimos a comienzos de siglo". ${ }^{168}$ Un aspecto que se debe destacar

${ }^{163}$ Arriaga, J. de. 1999 [1621]: Capítulo V.

164 Se trata de pequeños pueblos que no contaban con la arquitectura monumental que se podía ver en el Cuzco.

165 Epístola del Concilio, en Doctrina Christiana... 1584.

166 Valenzuela, J. 2006. "Imágenes y reliquias en la cristianización del Perú (1569 - 1649)... que las ymagenes son los ydolos de los christianos". Anuario de Historia de América Latina 43: 41-65.

167 Murra, J. 1975, "La función del tejido en varios contextos sociales y políticos", en J. Murra, Formaciones económicas y políticas en el mundo andino: 144-170 Lima: IEP. Flores Ochoa, J. 1978. "Clasificatión et dénomination des camélidés sud-américains". Annales E.S.C. 33 (5-6) : 10061016. Ascher, M. y Ascher, R. 1981. Code of quipu Databook: Ann Arbor: University of Michigan Press.

${ }^{168}$ Urton, G. "De nudos a narraciones. Reconstrucción del arte de llevar registros históricos en los Andes a partir de transcripciones en español de los khipus incaicos", en T. Bouysse-Cassagne. 1997. Saberes y memorias en los Andes. In memoriam Thierry Saignes : 303-323 : 304 París-Lima : Institut des Hautes Études de l'Amerique Latine y Institut Français d'Études Andines. Es 
es el fuerte grado de abstracción de los códigos textiles; un ejemplo interesante en este sentido es el estudio acerca de las talegas de Isluga realizado por Verónica Cereceda, trabajo en el que se detiene a analizar el carácter animal de dichas bolsas, significación que requiere una operación de síntesis muy alejada de las lógicas del arte occidental. ${ }^{169}$ No es posible detenerse en este artículo a identificar las probables interferencias que producirían en los indios los códigos textiles a la hora de interpretar las pinturas murales de las iglesias, ${ }^{170}$ no obstante, se puede afirmar que esa poderosa arma para subyugar -las imágenes pintadas en los muros- albergaba el germen de una resistencia a través de claves de lectura que siempre fueron desconocidas para españoles y criollos.

Es difícil abordar todas las prácticas y contenedores de memoria que pudieron interferir en el funcionamiento del sistema de catequesis. Muchos de los formatos, como los quipus o las tablas de la Casa del Sol descritas por Sarmiento de Gamboa, fueron destruidos o su lectura no es accesible. Especial relevancia debieron tener los keros en este proceso, ${ }^{171}$ cuya iconografía se fue transformando desde los inicios de la conquista $\mathrm{y}$, con mayor intensidad, a partir de las ordenanzas del virrey Toledo. ${ }^{172}$ La evolución de estos vasos rituales durante el período colonial está marcado por las restricciones, la resistencia a la supresión total de ciertas soluciones, así como por la adopción en sus paredes de formas occidentales; quizá sea un buen ejemplo de lo que pudo ocurrir en el ámbito de la memoria, un complejo entramado cultural en el que se entrecruzaron las imposiciones, la persistencia de prácticas locales, junto a la asimilación del ars memorativa. ${ }^{173}$

interesante revisar el trabajo de Frank Salomon acerca de la sobrevivencia de khipus en la aldea de Tapicocha en Perú. Salomon, F. 2004. The cord keepers. Khipus and cultural life in a peruvian village: Durham y Londres: Duke University Press.

${ }^{169}$ Cereceda, V. 2010. "Semiología de los textiles andinos: las talegas de Isluga”. Chungará 42 № 1: 181-198: 191.

170 Debe recordarse que hasta mediados del siglo XVII los khipus fueron usados en algunos lugares para facilitar la enseñanza del catecismo. Mujica Pinilla, R. 2002. "El arte y los sermones", en El Barroco Peruano : Lima: Banco de Crédito : 240.

${ }^{171}$ Vaso ceremonial andino que se caracteriza por su ornamentación y por tener la boca más ancha que la base.

172 Martínez, J.L. 2012. "El virrey Toledo y el control de las voces andinas coloniales". Colonial Latin American Review 21, № 2: 175-208.

173 Un trabajo interesante que trata precisamente de la ductilidad del mundo andino para apropiarse de nuevas formas de memoria es el de Simard, J.P. 1997. "Testamentos indígenas e indicadores de transformación de la sociedad indígena colonial (Cuenca, siglo XVIII)", en Bouysse-Cassagne, T., 1997: 279-299. 


\section{CONCLUSIONES}

Los habitantes de Parinacota, Pachama, Curahuara de Carangas y Copacabana de Andamarca aprendieron el catecismo mirando las imágenes que se encontraban pintadas en los muros de las iglesias, recitaban las fórmulas con una cadencia característica mientras veían en formas y colores lo mismo que estaban repitiendo. Al mismo tiempo, con una regularidad muy variable, escucharían sermones que, apoyándose en las representaciones pictóricas, profundizaban o complementaban lo aprendido por medio del catecismo. Algunos indios declamarían las sentencias aprendidas mientras desarrollaban sus labores cotidianas, trayendo a su memoria las palabras, las imágenes y el lugar donde cada una de ellas se encontraba en el templo. Quizá otros recorrerían con la memoria la iglesia para dar con una pintura y recordar así algún aspecto específico de la doctrina. Esta metodología, propia del arte de la memoria en su versión escolástica, debía estar al servicio de la virtud de la prudencia, ayudando -con su batería de palabras e imágenes correctamente articuladas- a desechar el mal y elegir el bien; al menos así lo concebían los sacerdotes y quizá, en parte, así fue para la población andina que debía ser catequizada.

Las prácticas andinas pudieron interferir en la ejercitación del arte de la memoria. Algunas formas culturales tal vez facilitaron la evangelización y catequesis. Por ejemplo, los indios repetían sus historias entonando canciones en contextos rituales $\mathrm{y}$, luego, al ser evangelizados, recitaban el catecismo dentro del espacio sagrado. También podría existir una similitud en la lógica de asociar la memoria a lugares; en la concepción andina visitar las wakas y los malquis era condición indispensable para activar estos sitios de la memoria, de un modo semejante operaba la catequesis que requería recorrer la iglesia para repetir la sentencia frente a la imagen correspondiente. Junto a estas simetrías que facilitarían la evangelización y posterior catequesis, se pueden identificar algunos rasgos que habrían entorpecido la ejercitación de la memoria. Por una parte, tal como señalan las fuentes, la memorización de largos relatos era un oficio practicado por unos pocos, la mayoría de la población presentaba dificultades para aprender un breve texto, situación que recoge el propio catecismo limense. Otra diferencia significativa era que la memorización se hace frente a pinturas, no frente a wakas, en consecuencia, podía ocurrir que se considerase a las pinturas como carentes de la fuerza suficiente para desempeñar su función 0 , por el contrario, que se acabase creyendo que esas representaciones pictóricas eran wakas. Un análisis más detenido ameritarían las distorsiones que pudieron provocar los códigos de los textiles en la interpretación de las pinturas murales, particularmente en una población poco o nada acostumbrada a representaciones de marcado carácter figurativo. 
Lo cierto es que quienes habitaron los pueblos de la Ruta de la Plata, como en otras localidades andinas, debieron asimilar, al menos parcialmente, el cultivo de la memoria con el fin de ejercitarse en la vida prudente. El edificio de la iglesia, las pinturas de sus muros, las fórmulas del catecismo y las palabras del sacerdote quedarían impresas en su memoria con el carácter de un sistema perfectamente articulado que se activaba cada vez que la conciencia se veía enfrentada a un dilema moral.

\section{FUENTES}

Acosta de, Joseph de. 1979 [1590]. Historia Natural y Moral de las Indias: México: Fondo de Cultura Económica.

Arriaga, Joseph de. 1999 [1621]. La extirpación de la idolatría en el Piru: Cuzco: Centro de Estudios Regionales Andinos "Bartolomé de las Casas".

Catecismo del Santo Concilio de Trento para los párrocos. 1782 [1584]. Valencia: Benito Monfort.

Cobo, B. 1989 [1629]. Historia del Nuevo Mundo: Sevilla: Imprenta de E. Rasco.

Constituciones sinodales del Arzobispado de la Plata. 1854 [17721773]. Argandoña P. M., ed.: Cochabamba: Imprenta de los Amigos.

Doctrina Christiana y catecismo para instrucciones de los indios, $y$ de las demás personas que deben ser enseñadas en nuestra Santa Fe. 1584. Lima: Antonio Ricardo impresor.

Durán, J. G. 1984. Monumenta catechetica hispanoamericana: Buenos Aires: Facultad de Teología de la Pontificia Universidad Católica Argentina, Santa María de los Buenos Aires.

Tercer Concilio Limense, 1582-1583: 1982: Lima: Facultad Pontificia y Civil de Teología de Lima.

Tercero Catecismo y exposición de la doctrina cristiana por sermones, para que los curas y otros ministros prediquen y enseñen a los indios y a las demás personas: 1773 [1584]: Lima. 
Guaman Poma de Ayala, Felipe. 2008 [1615]. Nueva Corónica y buen gobierno: Tomo II, Lima: Fondo de Cultura Económica.

Valadés, Fray Diego de. 1579. Rethorica Christiana: Perugia.

\section{BIBLIOGRAFÍA}

Ascher, M. y Ascher, R. 1981. Code of quipu Databook: Ann Arbor: University of Michigan Press.

Belting, H. 2009. Imagen y culto. Una historia de la imagen anterior a la era del arte: Madrid: Editorial Akal.

Bouysse-Cassagne, T. 1997. Saberes y memorias en los Andes. In memoriam Thierry Saignes: París-Lima : Institut des Hautes Études de l'Amerique Latine y Institut Français d'Études Andines.

Bouysse-Cassagne, T. 2000. "Les mots, les morts et l'ecriture: artes de la mémoire et évangelisation dans les Andes". Cahiers des Amériques Latines $33:$ 57-80.

Briones L. y Villaseca P. 1984. Pintura Religiosa en Tarapacá. Fe y color en el desierto: Chile: Ed. Cabo de Hornos Ltda.

Carruthers, M. 2000. The Craft of Thought: Meditation, Rhetoric and the Making of Images, 400-1200: Cambridge: Cambridge University Press.

Castro N., Chacama J. y Mir R. 2009. "Excitar y subyugar. Pastoral de la imagen y poblaciones indígenas en Arica Colonial". Diálogo Andino 34: 25-43.

Castro, V. 2009. Evangelización y religión andina en los Andes del sur: Santiago: Fondo de publicaciones americanistas y Centro de Investigaciones Diego Barros Arana.

Cereceda, V. 2010. "Semiología de los textiles andinos: las talegas de Isluga". Chungará 42 № 1: 181-198. 
Chacama, J. 2009. "Imágenes y palabras, dos textos de un discurso: La prédica pastoral en los Andes coloniales. Doctrina de Codpa (Altos de Arica), siglo XVIII". Diálogo Andino 33: 7-29.

Corti, P., Guzmán, F. y Pereira, M. 2009. "El Juicio Final de Parinacota", en Campos, N. (ed.) 2009. Entre cielos e infiernos, V Encuentro Internacional sobre Barroco, 115-124 La Paz: Unión Latina, Griso y Fundación Visión Cultural.

Corti, P., Guzmán, F. y Pereira, M. 2009. "La Pintura Mural de la Iglesia de San Santiago de Curahuara de Carangas como Patrón Iconográfico de la Iglesia de la Natividad de Parinacota", en Campos N. (ed). 2009. Entre cielos e infiernos, V Encuentro Internacional sobre Barroco, 125-132. La Paz: Unión Latina, Griso y Fundación Visión Cultural.

Corti, P., Guzmán, F. y Pereira, M. 2013. La pintura mural de Parinacota, en el último bofedal de la ruta de la plata: Arica: Fundación Altiplano-Universidad Adolfo Ibáñez.

Egido, A. 1986. "El arte de la memoria y El Criticón”, en: 1986. Gracián y su época: Zaragoza: Institución Fernando el Católico.

Estenssoro, J.C. 2001. "El simio de Dios. Los indígenas y la Iglesia frente a la evangelización del Perú, siglos XV-XVII". Bulletin Institute Français d' études andines 30: 455-474.

Flores Ochoa, J. 1978. "Clasificatión et dénomination des camélidés sud-américains". 1978. Annales E.S.C. 33 (5-6) : 1006-1016.

Fundación Altiplano (ed.). 2012. Iglesias Andinas de Arica y Parinacota, las Huellas de la Ruta de la Plata: Santiago: Quadgraphics.

Gerli, M. 1984. "El castillo interior y el arte de la memoria". Bulletin Hispanique $86 \mathrm{~N}^{\circ}$ 1-2: 154-163.

Gisbert, T. 1992. "La pintura mural andina". Colonial Latin American Review 1: 1-109.

Gisbert, T. 1998. Pintura mural en el área centro sur andina: La Paz: Ministerio de Educación, Cultura y Deporte-Organización de los Estados Americanos.

Gisbert T. 2008. "La Iglesia de Curahuara de Carangas", en La Iglesia de Curahura de Carangas: 41-55. La Paz: Plural Editores. 
Gisbert, T. 2009. El paraíso de los pájaros parlantes, la imagen del otro en la cultura andina: La Paz: Plural Editores.

Gisbert T. y Schauer, P. 2010. Iglesias rurales de La Paz y Oruro: La Paz: Editorial Gisbert.

Gruzinski, S. 1991. La colonización de lo imaginario. Sociedades indígenas y occidentalización en el México español. Siglos XVI-XVII: México: Fondo de Cultura Económica.

Jonathan, S. 2002. El palacio de la memoria de Matteo Ricci. Un jesuita en la China del siglo XVI: Barcelona: Tusquets Editores.

Lisi, F. L. 1990. El tercer concilio limense y la aculturación de los indígenas sudamericanos: Salamanca: Ediciones Universidad de Salamanca.

López Beltrán, C. 1990. Potosi-Arica, trazado de un recorrido: La Paz: manuscrito inédito.

López Beltrán, C. 2004. "Los circuitos del comercio colonial en Charcas (hoy Bolivia)", en H. Silva (ed.), Los caminos del MERCOSUR. Historia Económica Regional. Etapa colonial: 33-54. México: Instituto Panamericano de Geografía e Historia.

Martínez, J.L. 2012. "El virrey Toledo y el control de las voces andinas coloniales". Colonial Latin American Review $21 \mathrm{~N}^{\circ}$ 2: 175-208.

Moreno, R. y Pereira, M. 2011. La Iglesia en la Ruta de la Plata: Viña del Mar: Ediciones Altazor.

Mujica Pinilla, R. 2002. "El arte y los sermones", en El Barroco Peruano: Lima: Banco de Crédito.

Mujica Pinilla, R. 2003. "Identidades alegóricas: lecturas iconográficas del barroco al neoclásico", en El Barroco Peruano 2: 251335. Lima: Banco de Crédito.

Mujica Pinilla, R. 2006. “' 'Reading without book' -On sermons, figurative art, and visual culture", en Stratton-Pruitt, S. The Virgin, Saints, and Angels, South American paintings 1600-1825 from the Thoma collection: Stanford : Skira editore.

Murra, J. 1975. "La función del tejido en varios contextos sociales y políticos", en J. Murra, Formaciones económicas y políticas en el mundo andino: 144-170 Lima: IEP. 
Réau, L. 1998. Iconografía del arte cristiano: Tomo 1, Volumen 2, Barcelona: Ediciones del Serbal.

Rivers, K. 2010. Preaching the Memory of Virtue and Vice. Memory, Images, and Preaching in the Late Middle Ages: Brepols: Turnhout.

Rodríguez Valencia, V. 1957. El patronato regio de Indias y la Santa Sede en Santo Toribio de Mogrovejo (1581-1606): Roma: Iglesia Nacional Española.

Salomon, F. 2004. The cord keepers. Khipus and cultural life in a peruvian village: Durham- Londres : Duke University Press.

Schenone, H. 1992. Iconografía del Arte Colonial, los Santos: Buenos Aires: Fundación Tarea.

Simard, J.P. 1997. "Testamentos indígenas e indicadores de transformación de la sociedad indígena colonial (Cuenca, siglo XVIII)", en Bouysse-Cassagne, T. 1997. Saberes y memorias en los Andes. In memoriam Thierry Saignes: 279-299 París-Lima: Institut des Hautes Études de l'Amerique Latine y Institut Français d'Études Andines.

Siracusano, G. 2009. El poder de los colores. De lo material a lo simbólico en las prácticas culturas andinas. Siglos XVI-XVIII: Buenos Aires: Fondo de Cultura Económica.

Sebastian, S. 2007. El Barroco Iberoamericano: Madrid: Ediciones Encuentro.

Schmitt, J.C. 1992. "Imago: de l'image a l'imaginaire", en Baschet, J., y Schmitt, J.C. (dirs.)1996. L'image, Fonctions et usages des images dans l'Occident médiéval. Actes du 6e 'International Workshop on Medieval Societies. Erice, Sicile, 17-23 octobre 1992: 29-57 Paris.

Schmitt, J.C. 1996. "La culture de l'imago". Annales 1: 3-36: 4.

Taylor, R. 1987. El arte de la memoria en el nuevo mundo: El Escorial: Editorial Swan.

Urton, G. 1997. "De nudos a narraciones. Reconstrucción del arte de llevar registros históricos en los Andes a partir de transcripciones en español de los khipus incaicos", en Bouysse-Cassagne. T. Saberes y memorias en los Andes. In memoriam Thierry Saignes : 303-323 : París- 
Lima : Institut des Hautes Études de l'Amerique Latine y Institut Français d'Études Andines.

Vargas, R. 1951-1954. Concilios Limenses (1551-1772): Lima: Tipografía Peruana S. A.

Valenzuela, J. 2006. "Ambigüedades de la imagen en la cristianización del Perú. Trento, los jesuitas y el Tercer Concilio". Investigaciones Sociales año X No 17.

Valenzuela, J. 2006. "Imágenes y reliquias en la cristianización del Perú (1569 - 1649)... que las ymagenes son los ydolos de los christianos". Anuario de Historia de América Latina 43: 41-65.

Vergara, J. 2004. Historia y pedagogía del seminario conciliar en Hispanoamérica, 1536-1800: Madrid: Editorial Dykinson.

Yates F. 2005. El Arte de la Memoria: Madrid: Ediciones Siruela. 